\title{
THE PHOENICIAN FOOTPRINT IN IBIZA
}

\section{INTRODUCTION}

The Balearic archipelago, located east of the eastern coast of the Iberian Peninsula, is the westernmost in the Mediterranean. Together with Cyprus, Crete, Malta, Sicily and Sardinia, they constitute a series of stops that facilitated navigation in the Mediterranean during Antiquity.

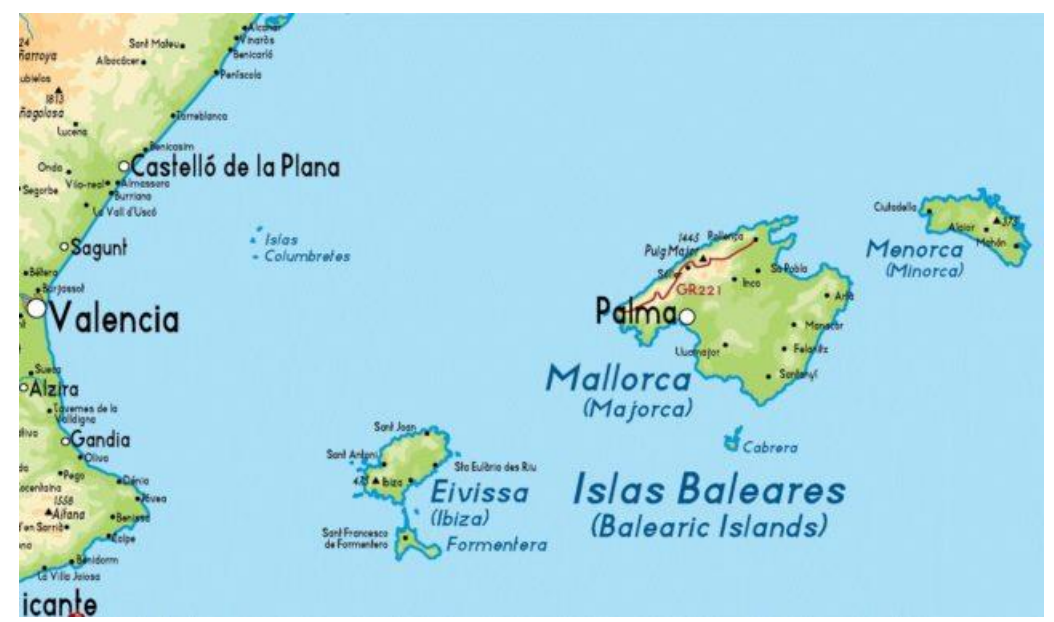

Within the Balearic Islands there is a subarchipelago, the Pitiusas, formed by the islands of Ibiza and Formentera, as well as several islets. In Ibiza, the first remains of human presence date from the 3rd millennium BC, fact confirmed due to the discovery in Avenc des Pouàs of a human femur dated between the years $2290-2130$ BC, as well as some axes and bronze ingots of the Middle Bronze Age in other parts of the island.

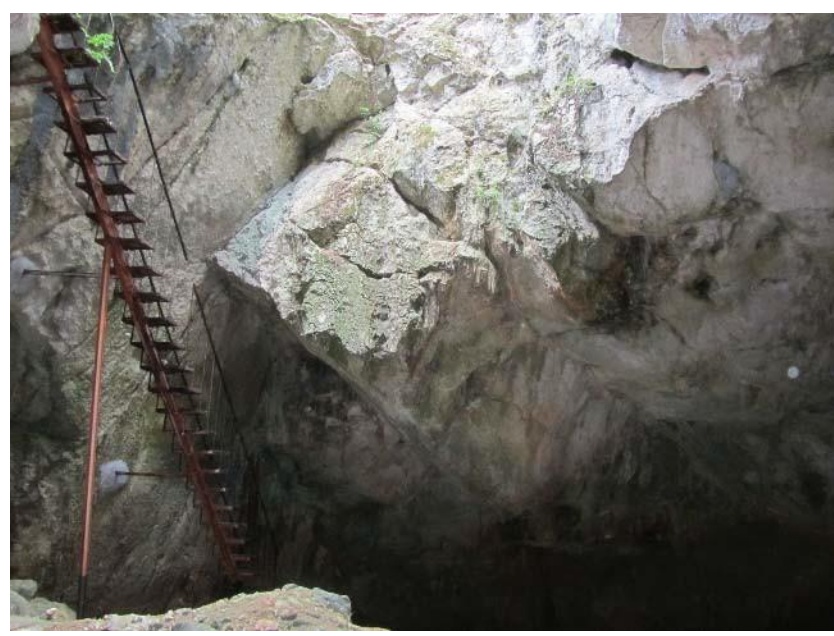

Avenc des Pouàs 
The oldest town in Ibiza is located in Puig de ses Torretes, dating from 1600 BC. Another outstanding archaeological site is in Can Sergent, where two corridor tombs built with large stone blocks have been found. Regarding the various ceramic remains found, they show obvious similarities with productions of the Initial Talayotic from Majorca and Minorca ${ }^{1}$.

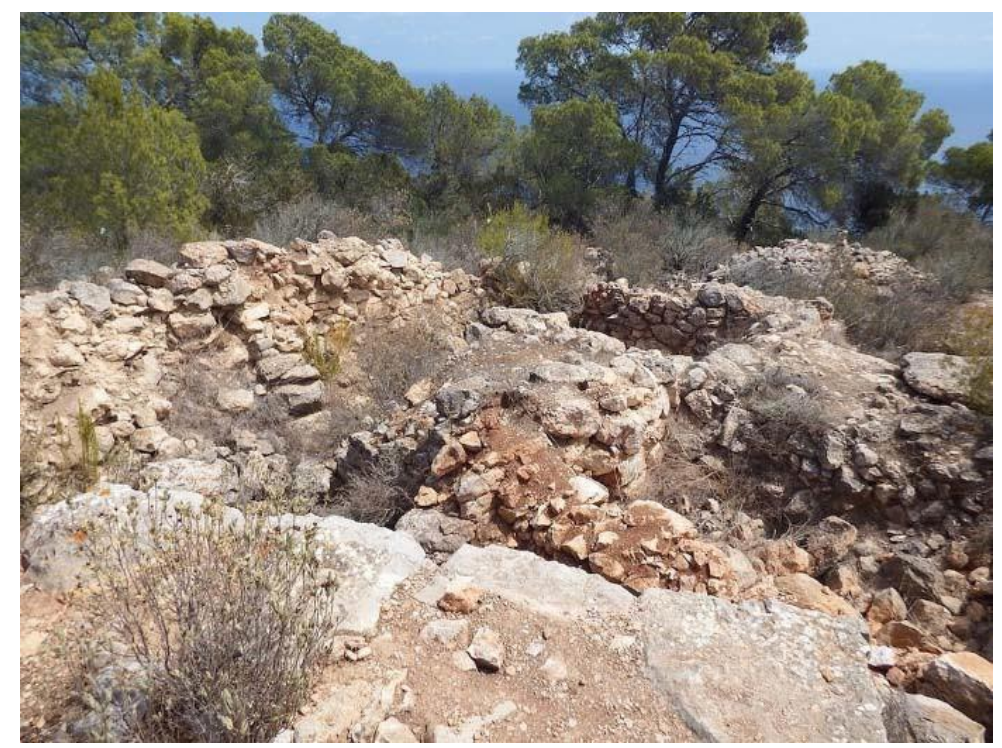

Archaeological remains in Puig de ses Torretes

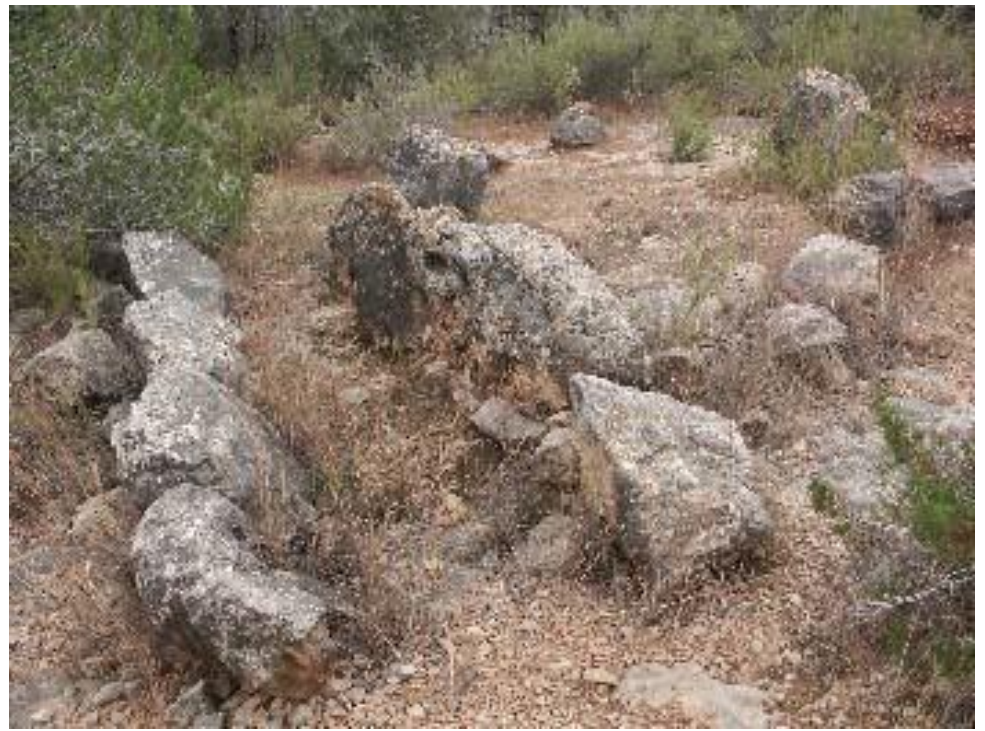

Can Sergent's corridor tomb in San José (Ibiza)

\footnotetext{
${ }^{1}$ This stage developed between the years 1500 and $1000 \mathrm{BC}$. It was characterized by the construction of large talayots of irregular structure, monuments of stepped section and the appearance of the first "table sanctuaries", as well as the first houses of circular plan. The burials were carried out inside buildings with an elongated plan, simple hypogea or in caves whose entrance was sealed with large stones.
} 
The orographic and environmental conditions of Ibiza differ significantly from those of Majorca and Minorca, especially in their level of rainfall and soil conditions. Geomorphologically, Ibiza is an extension of the Penibaetic System ${ }^{2}$, which runs along the Andalusian coast in southwest-northeast direction. Initially, neither the orography nor the geomorphological composition of the island show significant differences to other places in the Penibaetic System, fact that would not justify its relatively late human occupation. Among the reasons given that could justify it, it is worth mentioning the scarcity of food resources and watercourses, which would explain the absence of talayotic remains in Ibiza.

The study of the Phoenician and Punic eras of Ibiza has a long tradition, and is undoubtedly the best known in its history ${ }^{3}$. Among the literary sources of Antiquity that have provided us with more data on the foundation and colonization of Ibiza, is a text by Diodorus of Sicily (V, 16, 2-3) 4 that echoes what had previously been mentioned by Timarus of Tauromenius ${ }^{5}$, who stated that the foundation of the first settlement in Ibiza took place one hundred and sixty years after that of Carthage itself ${ }^{6}$, and that would have been one of the first actions of its subsequent expansion through the Mediterranean area.

From the text of Diodorus it is possible to make several interpretations. If taken literally, there would be no doubt in attributing the foundation and colonization of Ibiza to the Carthaginians, but for some researchers this interpretation is far from valid (Ramón, 1981 a: 25-26; Barceló, 1985: 271-282; ídem, 1988: 127-130; Costa, Fernández and Gómez, 1991: 759-760; Costa 1994: 89-97).

\footnotetext{
${ }^{2}$ The Penibeatic System is made up of a large number of landslide mantles, and its most notable geomorphological characteristics include the presence of Paleozoic lithic materials that suffered the effects of pre-Alpine metamorphism, which makes it abundant in various minerals such as iron, lead, copper and marble. The absence of post-Triassic sedimentary materials stands out.

${ }^{3}$ During Antiquity Ibiza was called Ebusos, Ebusus, Ebussos, Ebesos or Hebusos.

${ }^{4}$ Greek historian of the 1st century BC born in the Roman province of Sicily whose most outstanding work is the Bibliotheca Historica, composed of 40 volumes that collect the most relevant historical events that occurred between the Trojan War and the year 60.C BC.

5 (350-260 BC) After the conquest of Tauromenius (Taormina) in 316 BC by Agathocles, tyrant of Syracuse, he was forced into exile in Athens, where he devoted himself to producing various historical writings that, compiled into 38 volumes, narrate the Greek expansion through the western Mediterranean.

${ }^{6}$ According to Classical mythology, it was founded by Dido in 864 BC, although it is now considered to have taken place between 825 and 820 BC.
} 
The controversy over who founded the first settlement and colonized Ibiza, whether Phoenicians or Carthaginians, seems to be currently overcome thanks to different archaeological findings and the review of written sources made by authors such as Barceló (1985), who have shown that the traditional and, in many cases unconditional assumption of what was affirmed by Timarus and collected by Diodoro about the Punic foundation of Ibiza in the mid-7th century BC., does not allow to continue attributing it to Carthage.

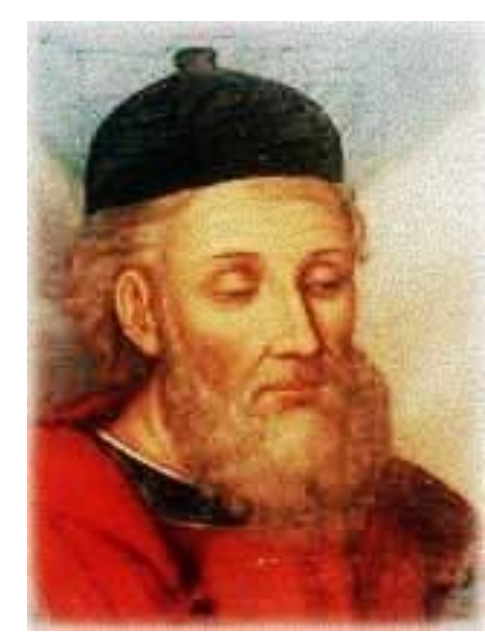

19th century portrait of Diodorus of Sicily

The origins of the first foundation of Ibiza must be related to the Phoenician expansion through the western Mediterranean area, since the characteristics of its sites and the archaeological material recovered, show undoubted parallels with those found in the Phoenician colonies of the western Mediterranean (Ramón, 1981 a, 1982 a, 1984, 1985 a, 1991 a; Fernández, Gómez and Gurrea, 1984; Costa, 1986, 1988 y 1991; Costa and Fernández, 1988, 1990 a, 1992 y 1993 a; Costa, Fernández and Gómez, 1991; Gómez, 1991 a, 1992, 1995 y 1996; Gómez et alii, 1990).

For most researchers, the colonization of Ibiza took place in two major phases:

- firstly, one related to the expansionist process of the commercial networks of the Phoenician colonies of the western Mediterranean, especially during the second half of the 7 th century BC. 
- and a second linked to the Punic expansion that from the central Mediterranean, incorporated various Phoenician enclaves under its influence from the last third of the 6th century BC.

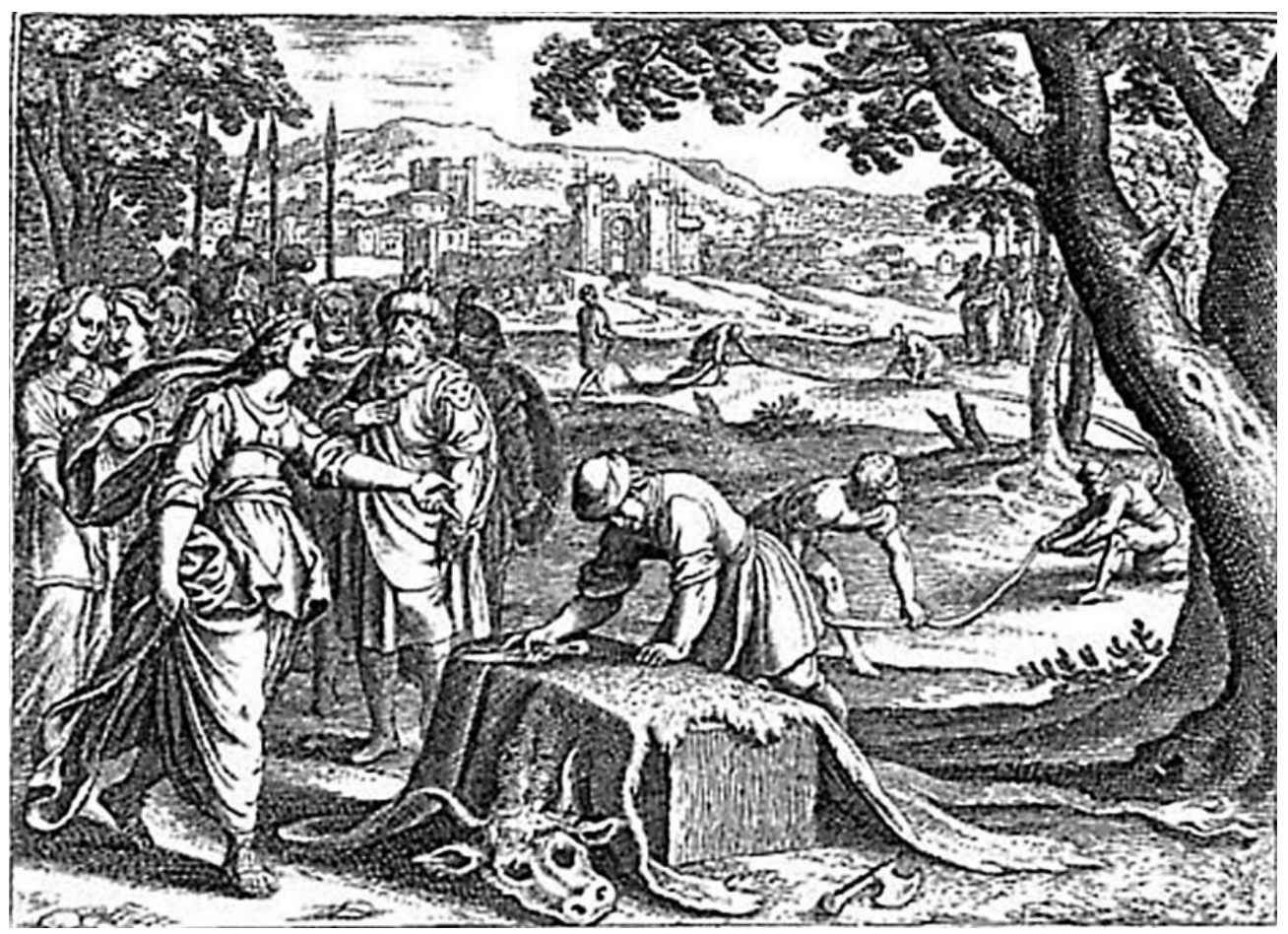

Foundation of Carthage by Dido, according to Matthäus Merian the Elder (1630)

\section{PHOENICIAN IBIZA}

The foundation of the first Phoenician enclave in Ibiza took place towards the middle of the seventh century BC.C. The scarcity of indigenous sites on the island does not allow us to know if there were Phoenician products o contacts before that date. Among the reasons that led the Phoenicians to settle on the island, it is worth mentioning the process of Phoenician colonial expansion of the 7 th century $\mathrm{BC}$ and the strategic location of Ibiza in their trade routes. This possibility was proposed in 1969 by Maluque after several Phoenician archaeological finds in the area of the Ebro Delta, but in relation to this hypothesis, it is possible to make certain observations. 

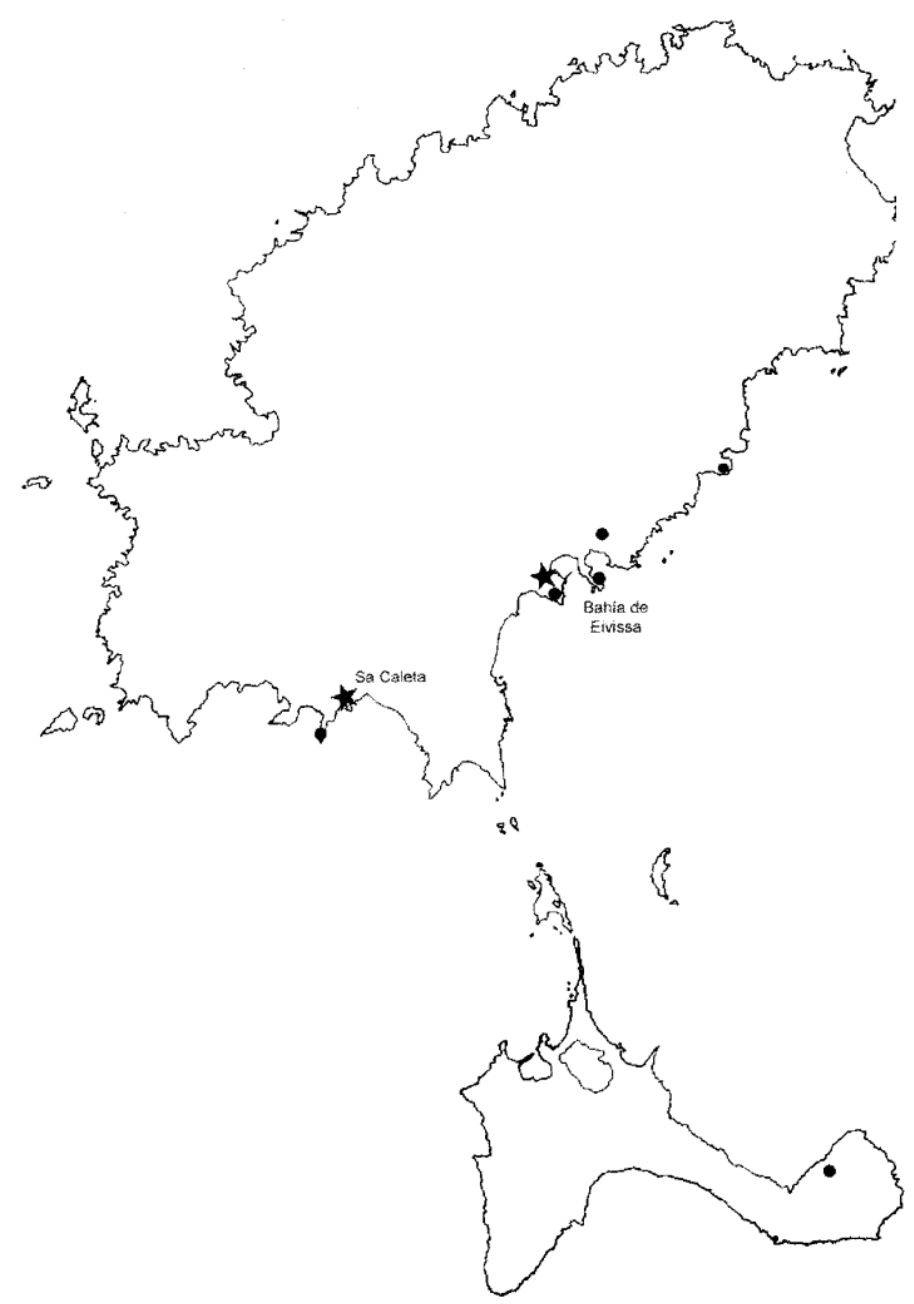

Main Phoenician archaeological finds in Ibiza and Formentera

One of them would be to know to what extent this commercial development on the eastern coast of the Iberian Peninsula is attributable to Ibiza, or if on the contrary the foundation of the Ibizan enclave was a consequence of the need to have a greater number of points of support due to the growth of a commercial network in full expansion. The archaeological remains found in the Valencian Community, Catalonia and the south of France, seem to confirm the first possibility, which allows us to get an idea of the importance of Ibiza as a distributor of goods and merchandise in the area, whose benefits allowed to settle the development and prosperity of the enclave (Costa and Fernández, 1997).

Other researchers (Aubet, 2009) opt for the second possibility, and they highlight that, both in the Alicante and Murcian areas, contacts had been taking place prior to the establishment of the Phoenicians in Ibiza, being possible that these areas were inserted 
in the range of action of the Phoenician colonies of eastern Andalusia. In the last moments of the 8th century BC is when the presence of Phoenician products is observed in the large indigenous villages of those areas (Los Saladares and Peña Negra in the province of Alicante and Castellar de Librilla in the Region of Murcia) thanks to the discovery of some amphorae and red slip ceramic pieces.

The strategic position of Ibiza allowed it to become an outstanding point in the navigation routes to the central and eastern Mediterranean. In addition, being practically uninhabited and its proximity to Majorca and Minorca, which had an important indigenous population that could constitute an interesting potential market for commercial exchanges, were strong arguments that justified their choice by the Phoenicians, who would begin to settle in it from the second half of the 7 th century BC.

In what could be considered as the first phase of the Phoenician settlement in Ibiza, approximately between the years 650 and $580 \mathrm{BC}$, it must have had nothing but the necessary infrastructure (anchorages, warehouses and the habitat necessary to cover the needs of the population) as a point of support in the commercial exchanges carried out between several areas of the Mediterranean. It is quite possible that, in order to achieve some self-sufficiency, the first Phoenician inhabitants of the island launched some agricultural initiatives in the lands closest to the bay of Ibiza.

Among the possible places where the Phoenicians could settle in Ibiza at first, Sa Caleta stands out. Since 1986, six excavations have been carried out at that site, where an estimable amount of archaeological remains have been found. Located on a small peninsula known as Sa Mola de Sa Caleta, whose maximum height above sea level barely reaches 16 meters, there is a strong erosion in its southwestern part due to the action of the sea, which has caused a partial loss of the original Phoenician settlement. According to archaeological evidence, it is estimated that the nucleus must have occupied an approximate area of four hectares, although currently only three are preserved. 


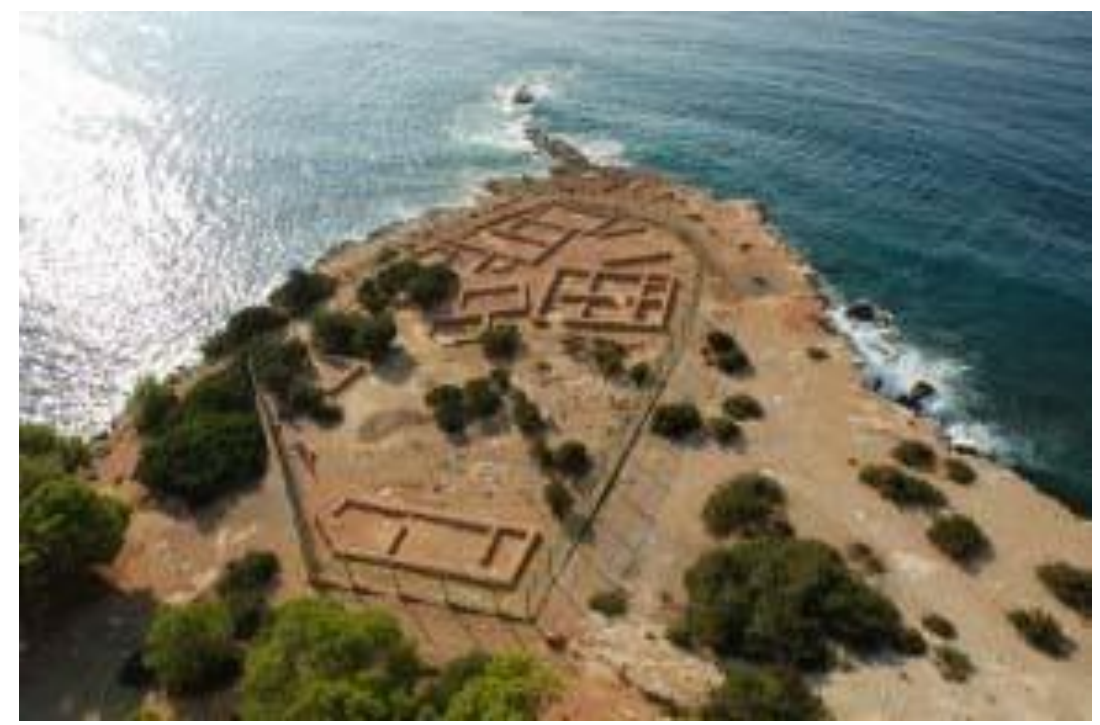

Aerial view of the Phoenician site of Sa Caleta

At first it was thought that the Phoenician settlement of Sa Caleta was nothing more than a mere place devoid of any kind of structures where trade was carried out with the indigenous population of the surrounding areas. Currently, and according to the data obtained after the study of the archaeological findings, it can be said that it was a settlement that followed the same guidelines of other Phoenician enclaves, such as its location on an easily defensible peninsula from which a small cove is protected, which would serve as an anchorage for ships, in addition to having a supply of drinking water.

The urban structure of the settlement of Sa Caleta is characterized by the presence of several buildings that have a variable number of juxtaposed housing units of generally rectangular plan (although there are also trapezoidal ones) and without defined orientation with respect to the others. The dimensions of these spaces depended on their purpose, ranging between 3 and $30 \mathrm{~m}^{2}$. Many of these structures were successively enlarged thanks to the addition of other spaces, the largest reaching a total of seven, which communicated with each other by means of relatively wide spans, some of them with stone thresholds. 


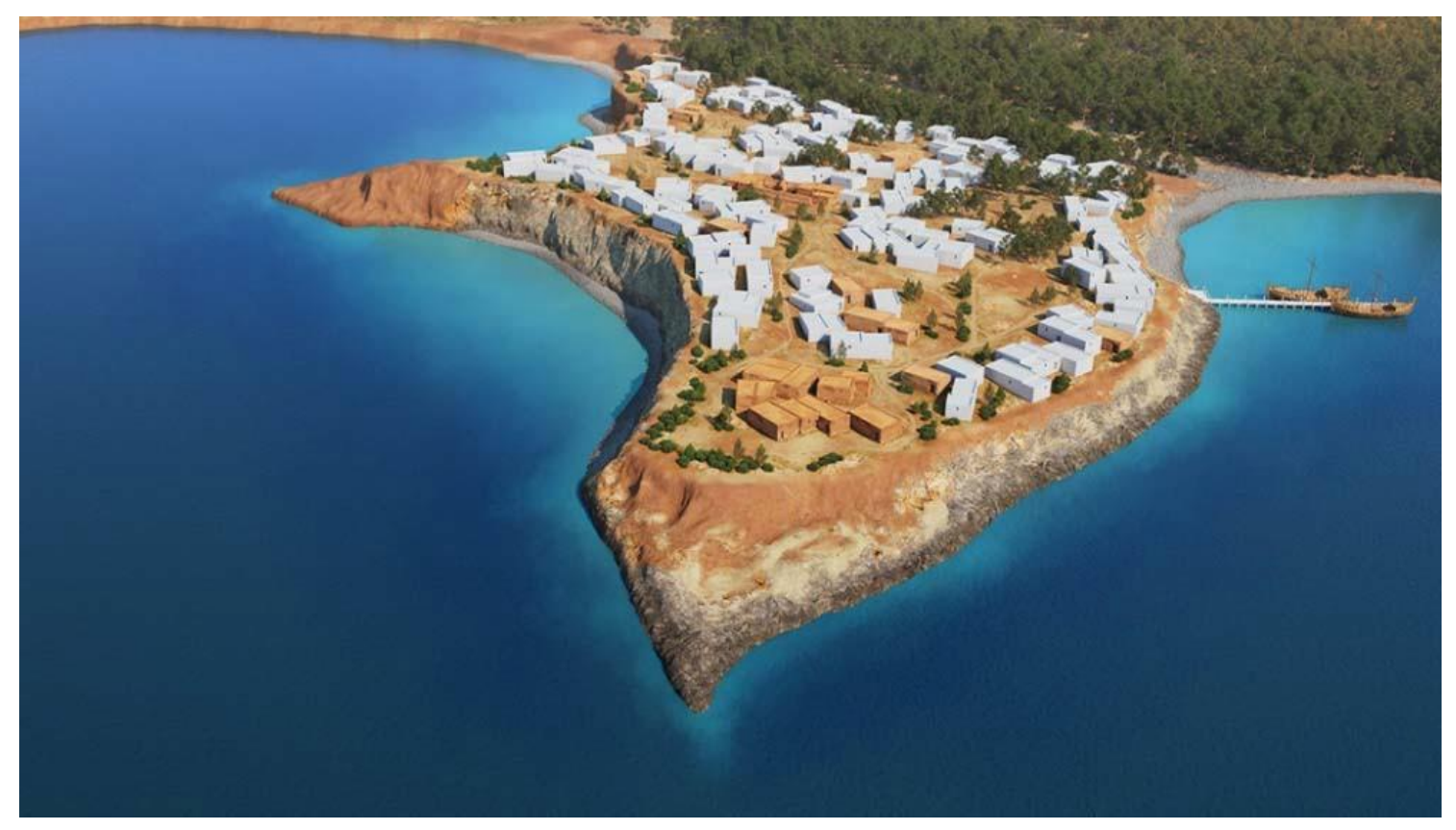

Reconstruction of the Phoenician settlement of Sa Caleta

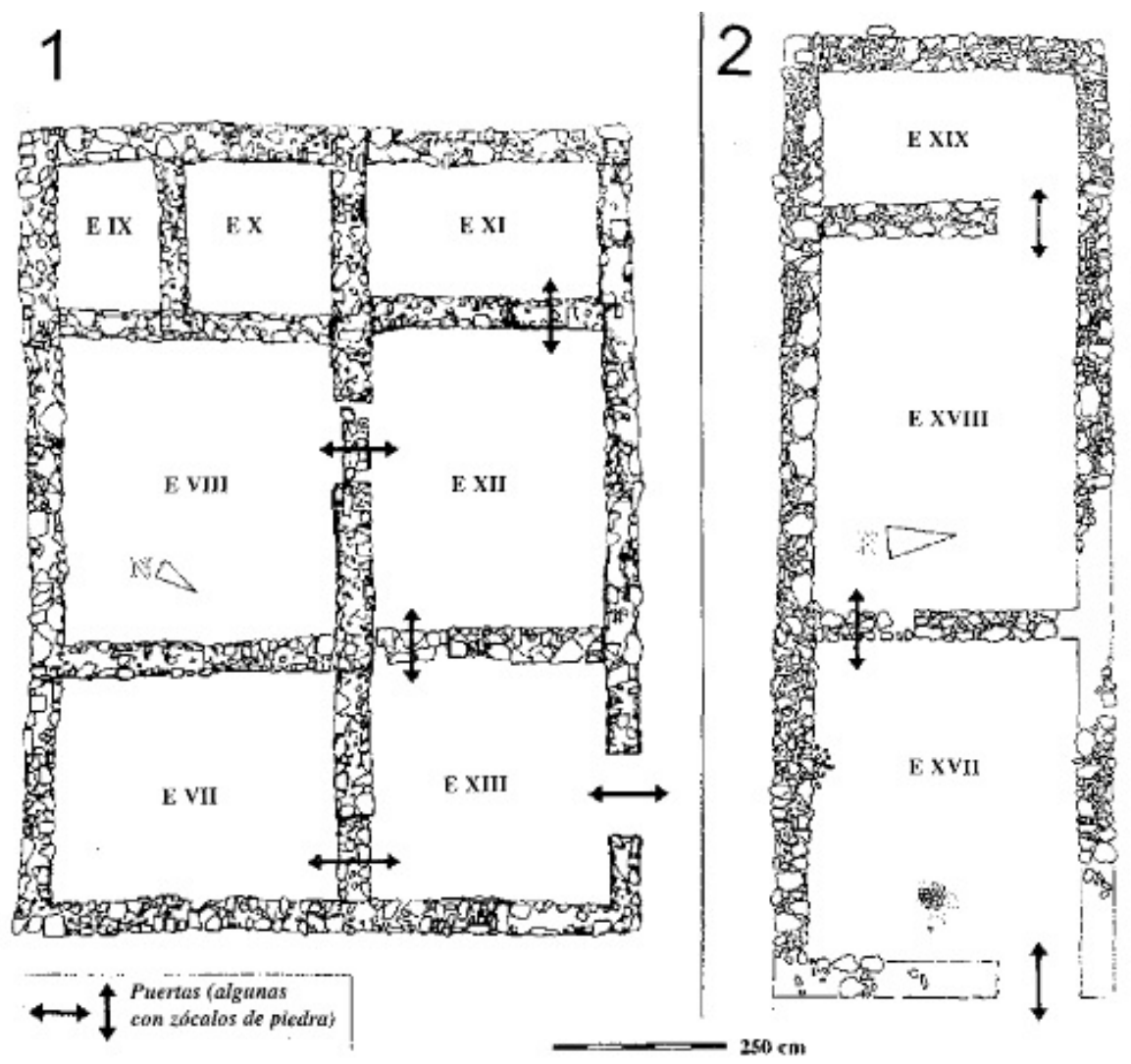

Plant of two houses of Sa Caleta (Ramón, 1996) 
As far as construction techniques are concerned, the entire settlement was built in the same way and with the same materials. The floors of the rooms are usually rammed earth, and the walls have a plinth of irregular stones of medium size, joined with a reddish paste obtained from local clay. It is currently unclear whether the rest of the elevation of the walls was made using adobe bricks or stone.

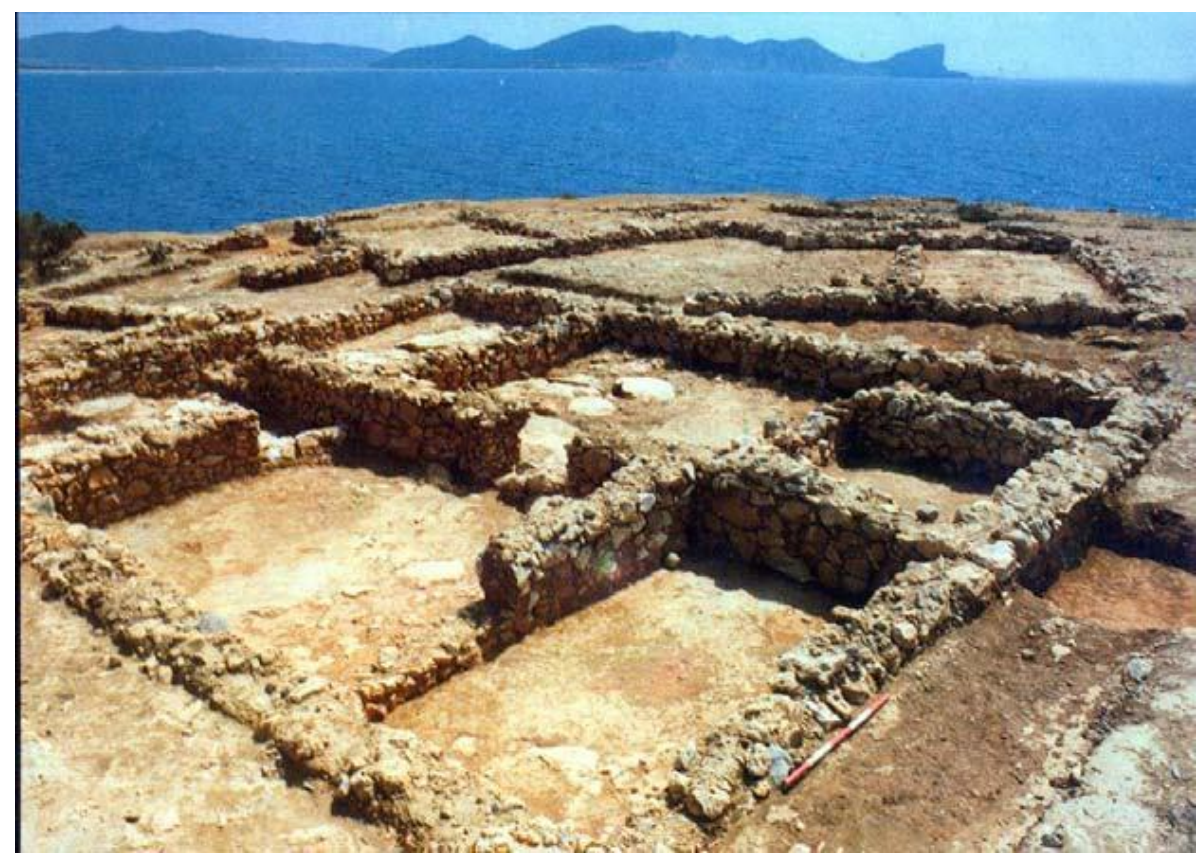

Remains of housing units of the Phoenician site of Sa Caleta

Among the different houses it has been found the presence of small and narrow alleys that led diagonally into small squares of polygonal plan, whose shape is a consequence of the lack of orientation of the surrounding buildings, which reveals a somewhat archaic urban planning.

The typology and nature of the remains found in Sa Caleta range from ceramic vessels with characteristics of Western Phoenician types, to amphorae of Punic and Central Mediterranean style. Some nonceramic objects such as argentiferous nodules have also been found in various places in the settlement, iron and bronze knives, grinding stones and bronze fishing hooks. 

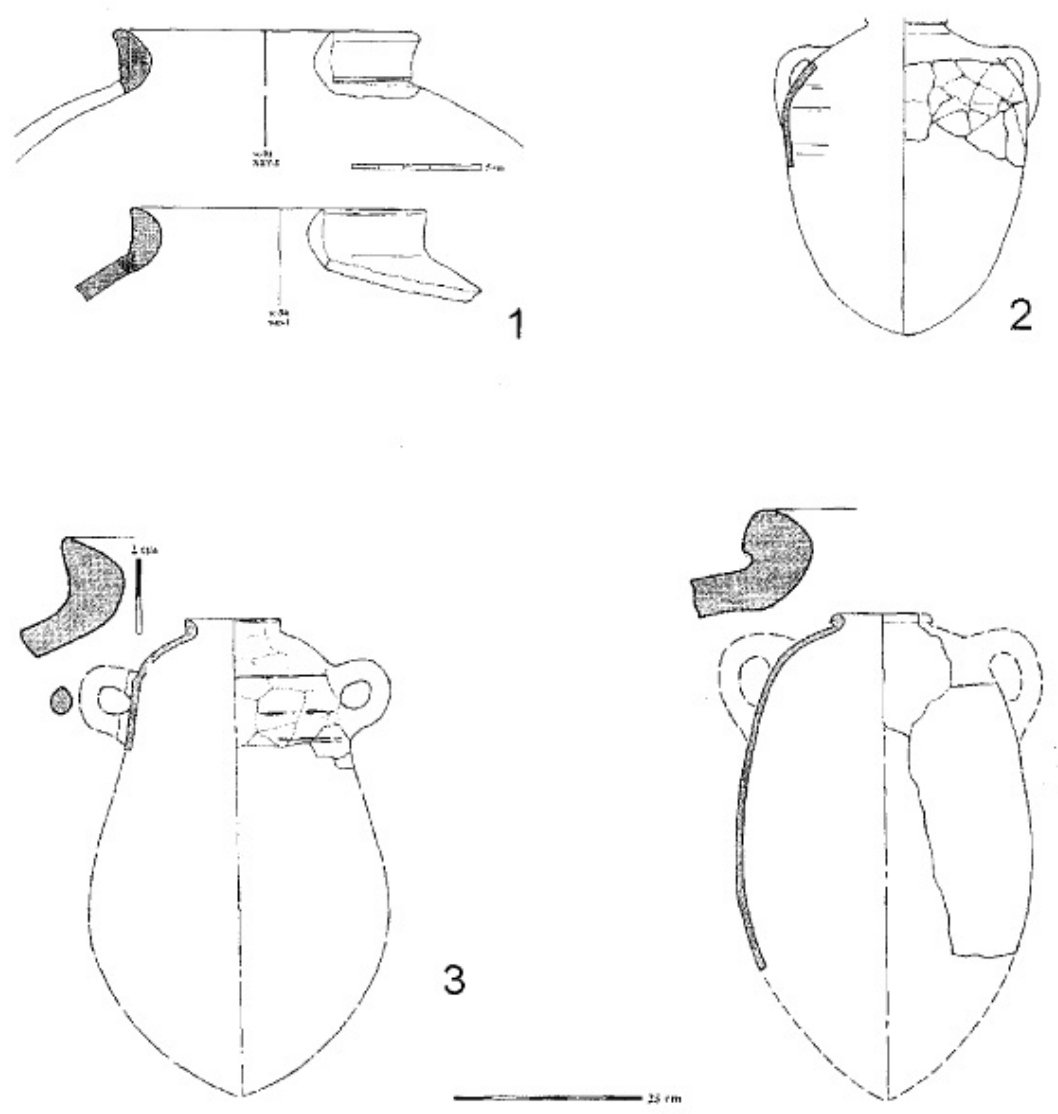

3

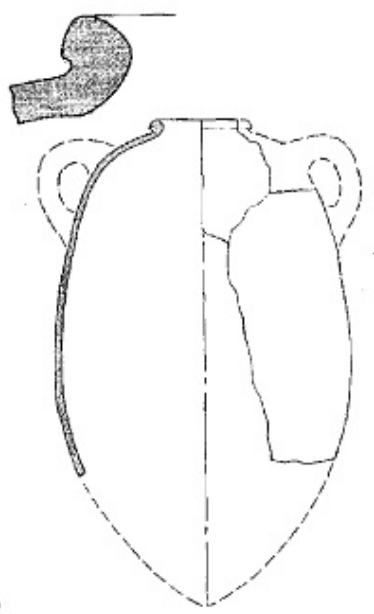

Amphorae types found in Sa Caleta (Ramón, 1996)

In general it can be said that Sa Caleta follows the patterns present in the Phoenician sites of the Andalusian coast, which is an important fact that seems to confirm that the first colonization of Ibiza was due to Phoenicians from the so-called "circle of the Strait".

In Sa Caleta it has only been possible to verify the presence of a single level of occupation, which indicates that it was occupied during a short time period that has been estimated that it should not have exceeded fifty years. The place was abandoned at the end of the 7th century BC in an organized and premeditated way, not being occupied again, although very sporadically, until the 3rd century BC. It is possible that the abandonment of the settlement of Sa Caleta in favor of another located in the bay of Ibiza was due to the better conditions of the latter. However, it seems that until about $650 \mathrm{BC}$ both settlements were in operation, and despite being relatively far from each other (about $10 \mathrm{~km}$ in a straight line) and separated by the Strait of Els Freus, whose navigation conditions are not always optimal, land communication between the two was simple. 
If one considers the location of the Phoenician settlements in the south of the Iberian Peninsula, the abandonment of Sa Caleta in favor of the bay of Ibiza should not have occurred, but among the reasons that justify this decision, is to have a stopover in its navigation route to the north of the Iberian Peninsula and the central Mediterranean. Also, and due to the small population of the island, most of its needs could be perfectly covered by a single center.

The establishment in the bay of Ibiza offered a series of advantages as it is a place relatively well protected against inclement weather, and ideal for the berthing of ships. To the west of the bay is the Puig de Vila, on whose northern and northwest slopes extends a plain, perfect for the disembarkation of goods, which extends to the east. Near the coast and further east, rises the Puig de Valls and the area of Talamanca, whose orography make it another favorable place to disembark. Finally, the west slope of Cap Martinet, located to the east, closes the space comprised by the bay.

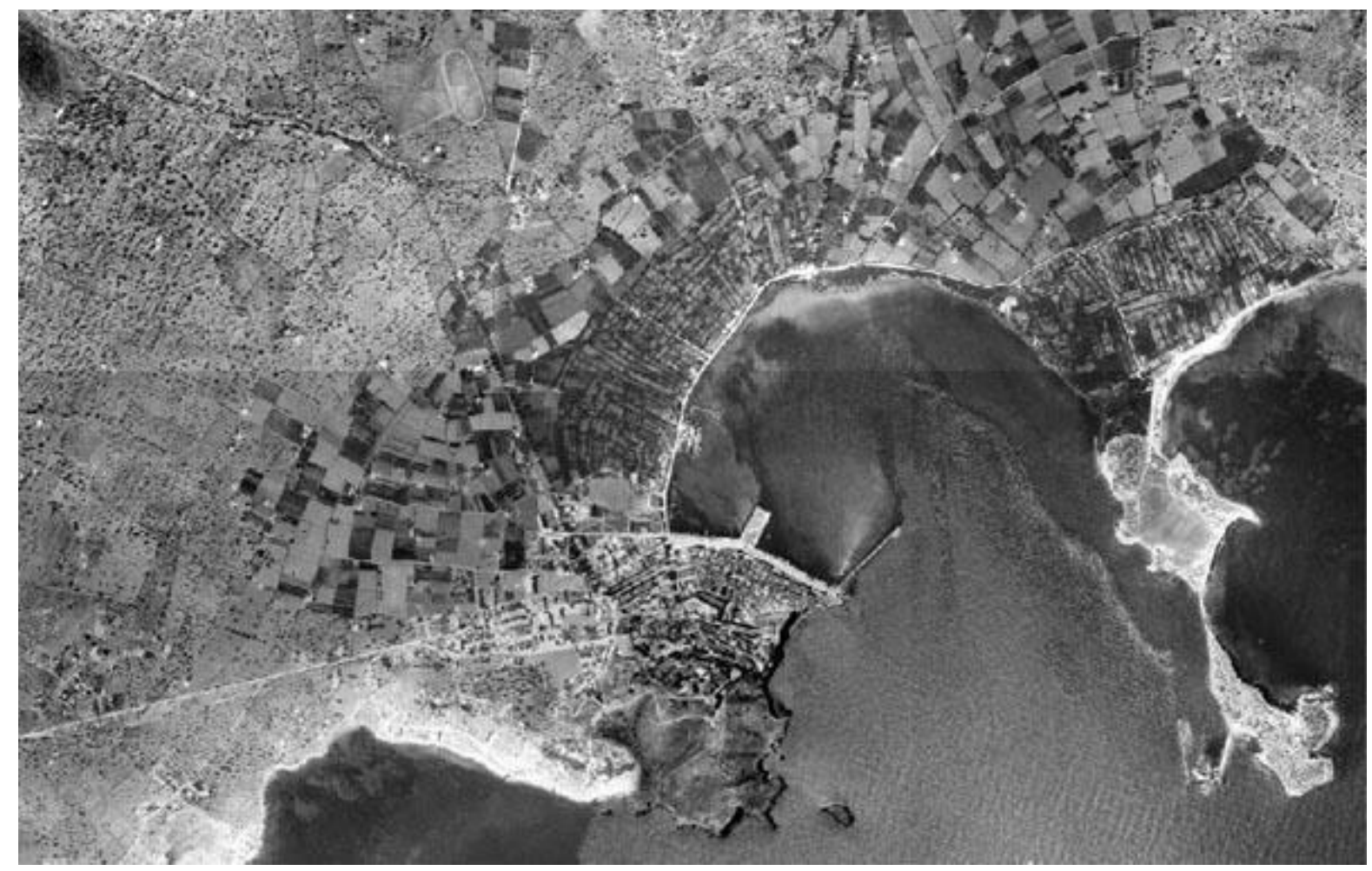

The bay of Ibiza at the present time 
In the center of the bay are two small islands, Illa Plana and Illa Grossa, in addition to the islet of Botafoc. In ancient times both islands were separated from the mainland, but today they are linked to the coast thanks to an arm of land and two breakwaters that have upset the original configuration of the bay by dividing it into the current bays of Ibiza and Talamanca. Until the construction of the aforementioned breakwaters, the most sheltered place of the bay was in an inlet located in the westernmost part of it, which being protected by the Puig de Vila, was where the Phoenician port must have been located.

In the Puig de Vila, whose summit has been successively occupied over time by at least three architectural elements such as a fortress, a citadel and a sanctuary or temple, is where the Phoenician population center was probably established, of which there is not enough archaeological evidence to ensure it. Had that been the case, it is speculated that it would have had some simple defensive system. In the place have been found very ancient ceramic remains, which seem to confirm the Phoenician presence from very early dates, which suggests that at the top of the Puig de Vila they must have erected some type of structure, perhaps a temple or fortification, although there is no record.

To the northeast of the Puig de Vila there are some hypogea whose most likely dating dates back to the 7th century $\mathrm{BC}$ which, despite the scarcity of data obtained after its study, suggests that the population center should not have extended beyond the top of the Puig de Vila, or if it did, it did not do so in that direction. In any case, it seems that this necropolis was not used for a long time, since the place was quickly urbanized soon after.

Between the seventh and sixth centuries a.C., as a result of the progressive urban growth of the settlement, the port ended up joining the population center, being likely that some type of installation was erected south of the Puig de Vila. In this area have been found R-1 amphoric fragments, pithoi urns and some arrowheads. Based on the evidence found, among which stand out a fragment corresponding to an Attic amphora found in the Bastion of Saint Lucia and an anthropomorphic lead figurine among the filling of the Bastion of San Juan, both dated from the sixth century BC, it can be inferred that these places were also occupied by the primitive Phoenician enclave. 
In a plain located between the north and northwest slope of the Puig des Molins there is an extensive necropolis that occupies an estimated area between 8,000 and 10,000 $\mathrm{m}^{2}$, which has an outstanding number of burials dated around the second half of the 6th century $\mathrm{BC}$ and the first quarter of the 5th century BC. This necropolis, located a few hundred meters from the port, includes various types of burials such as:

- charred skeletal remains, deposited in small circular holes or natural hollows in the rock, which were sometimes protected with small stone slabs placed vertically and diagonally.

- polychrome cinerary urns with an oval body and lobed handles, introduced in small circular holes dug into the rock or in natural cavities, always protected by stones. Other vessels were also used to contain the ashes of the deceased, such as pithoi or amphorae.

- small semirectangular graves of variable depth. Some have stone side cladding, although the vast majority lack these.

- rectangular graves with long and narrow tunnels leading into them. Normally they contain cremations carried out in those same places, being frequent to find in them limestone baetyls.

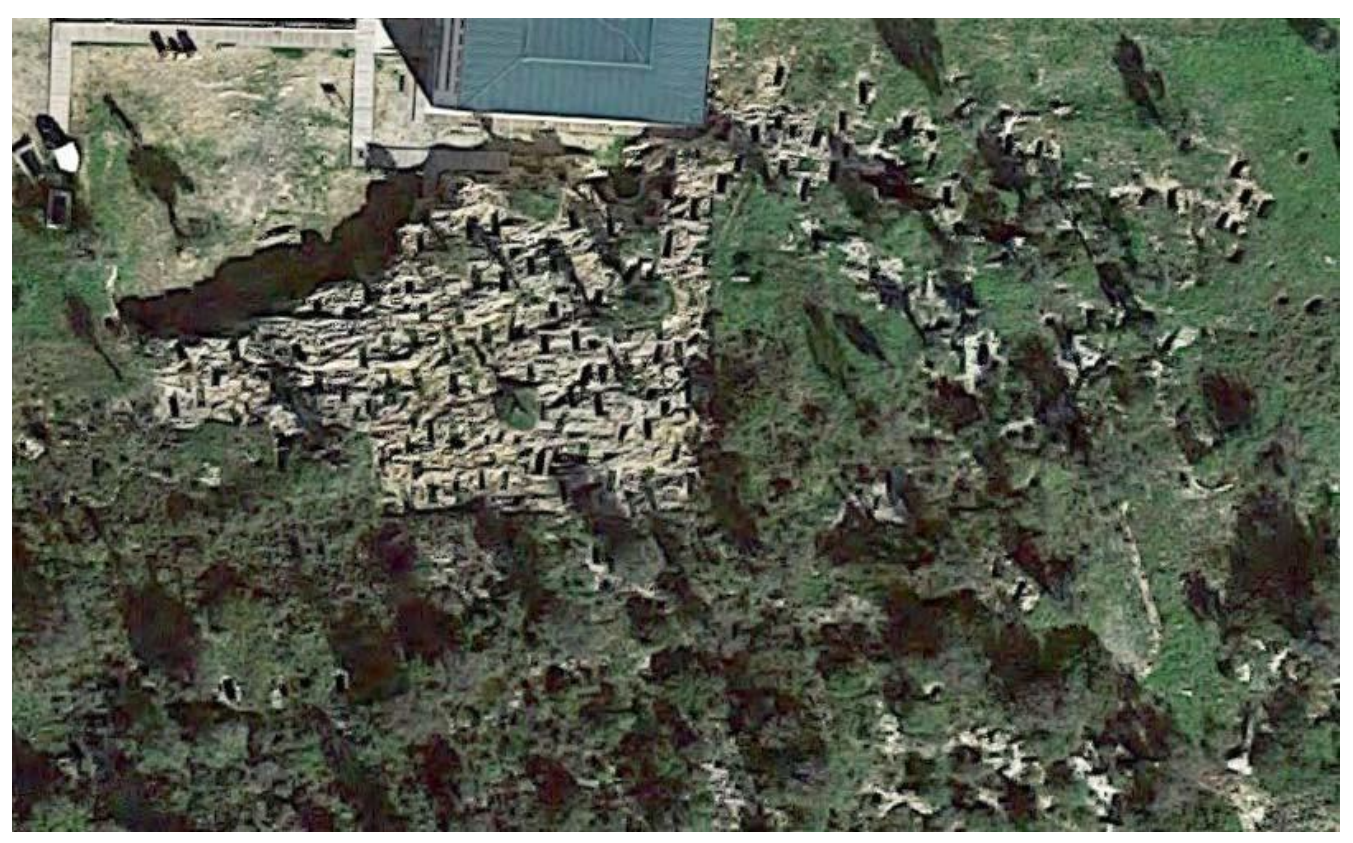

Aerial view of the necropolis of Puig des Molins 
The trousso in all of them is quite scarce, being limited to small perfumers of spherical body with a handle that must have contained oils or scented ointments. In some cases there are double beak lamps and wide containers, with their edges decorated in red, being the only ceramic pieces found next to the remains of the deceased. Some ornamental elements have also been recovered, such as a pair of earrings. One of them, circular in shape, has a hoop from which hung a small stone, and another to place it in the atrial lobe. The other, quadrangular, is very similar to the previous one. Both examples are made of silver and lack decoration.
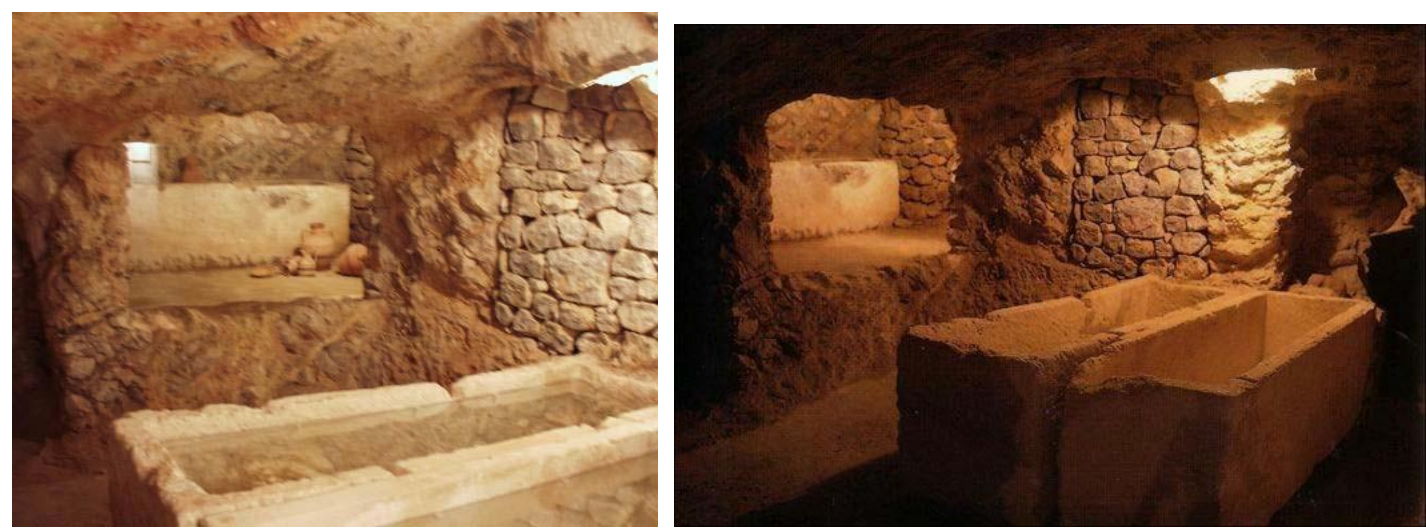

Interior of one of the burials of the necropolis of Puig des Molins

It is worth noting the discovery of several scarabs ${ }^{7}$ in the place. One of them has a hieroglyphic inscription that refers to Pharaoh Psamtik II (595-589 BC) ${ }^{8}$ There is another with two facing uraeus $^{9}$, dated to the 7 th or 6 th century BC, made of white faience ${ }^{10}$, which shows Horus seated, set in a silver circle. Perhaps this scarab is a product imported from Naucratis ${ }^{11}$. Another one, made with blue faience inserted in a

\footnotetext{
${ }^{7}$ Amulet that represents a dung beetle as a solar symbol and of resurrection, according to the religious beliefs of Ancient Egypt.

${ }^{8}$ Pharaoh of the XXVI dynasty who during his brief reign (although Herodotus and Eusebius of Caesarea claim that he reigned for seventeen years) directed his attention against the kingdom of Kush, where the descendants of the pharaohs of the 25th Dynasty reigned.

${ }^{9}$ Representation of the Egyptian goddess Wadjet in the form of a king cobra.

${ }^{10}$ Ceramic material with a vitreous appearance widely used in Ancient Egypt to make amulets, statuettes...

${ }^{11}$ First Greek commercial factory established in Egyptian territory between the 7th - 6th centuries BC, 72 $\mathrm{km}$ southeast of Alexandria.
} 
silver ring, represents a chariot drawn by horses and its driver, also very probably from Naucratis. Finally, it is worth mentioning the scarab found by J.M. Mañá in 1946, made of blue faience with an indecipherable motif, dated to the 7th or 6th centuries BC, as well as another mounted in silver, also made of faience, showing a winged sphinx.

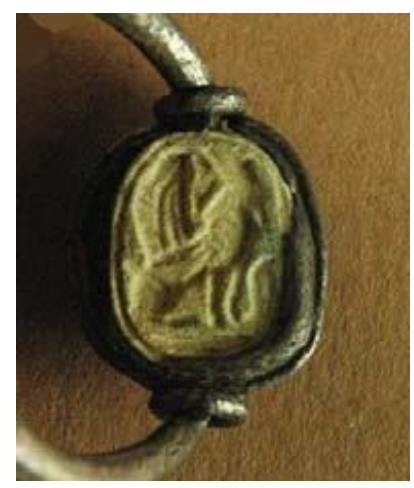

\section{Detail of one of the scarabs found in Puig des Molins}

The repertoire of ceramic containers used for the ashes of the deceased is certainly interesting. Most of them were made by hand, of which the most prominent are urns with a globular body and narrow concave and rectilinear edges that had a handle placed at the top. Others show a biconical tendency, and stand out for their wide mouth and flattened handles, located in their central section. Spherical vessels with wide mouths and prominent handles have also been found, decorated with rectilinear circles.

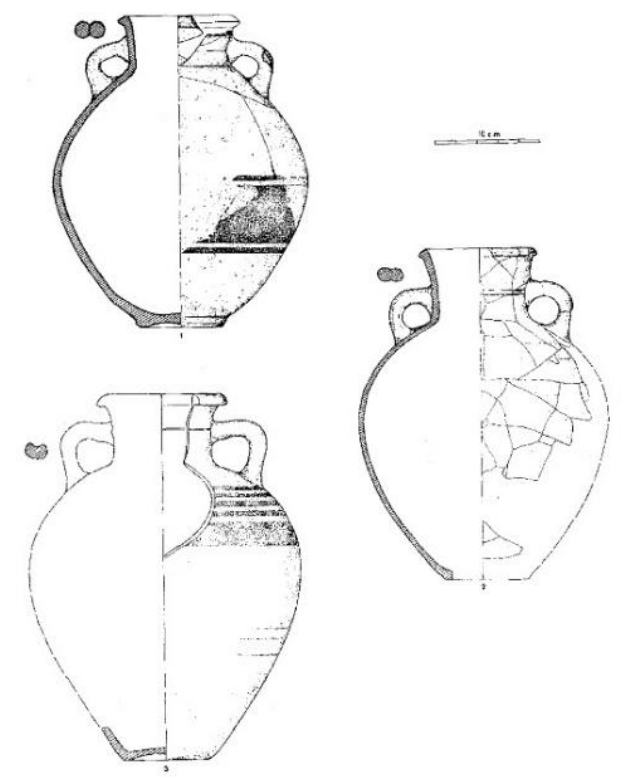

Funeral urns found in Puig des Molins 
The location of the necropolis of Puig des Molins has attracted attention for not following what was observed in other Phoenician enclaves, such as those in the south of the Iberian Peninsula. Although the graves are located at a certain distance from the population center, they are not on a hill or promontory on the other side of a river, as can be seen in Toscanos or Morro de Mezquitilla, for example. If it had followed a pattern similar to that seen in other Phoenician settlements, in the case of Ibiza the necropolis should have been in Puig d'en Valls, a place that will not be used until well into the 6th century BC. Perhaps its location in Puig des Molins was due to the fact that at first, and possibly due to the ritual needs of the primitive settlement or due to orographic conditions, they opted for a solution somewhat different from what was usual in other places.

\section{IBIZA AND ITS CONTACTS WITH THE CENTRAL MEDITERRANEAN}

This second stage of Phoenician Ibiza, which will take place approximately between 580 and $540 \mathrm{BC}$, was characterized by a process of adaptation to the new economic circumstances that will arise as a result of a crisis that is the subject of several hypotheses that had significant repercussions on Phoenician trade flows.

Sometimes the interest shown by the Phoenician colonies of the "circle of the Strait" in the east and northeast of the Iberian Peninsula led to some conflicts with their Tartessian neighbors. For authors such as Gómez Bellard and Costa (1990), it was far from being sudden and should be framed within the progressive process of expansion that, from the east of Andalusia, had begun long before the outbreak of that crisis, of which the Phoenician settlement on Ibizan soil is proof. It seems logical to deduce that the expansion of trade routes to the south of France was due to the presence in that area of some goods and raw materials of interest, such as tin.

At the beginning of the 6th century BC. Phoenician relations with the northeast of the Iberian Peninsula seem to be consolidating, but due to the crisis of the Andalusian Phoenician factories and the foundation of the Phocaean ${ }^{12}$ enclaves of Massalia ${ }^{13}$ in the

\footnotetext{
12 Phocaea (present-day Foça, Turkey) was an ancient lonian city in Asia Minor founded in the 8th century BC. by groups of settlers from Erythres and Teos. It became a prominent commercial enclave throughout the Mediterranean and founded colonies such as Massalia (Marseille, France).

13 Original name of Marseille (France). Founded by Phocaean Greeks in 600 BC, it became an important commercial and cultural center by spreading Hellenism among the different peoples of Gaul. Its inhabitants founded enclaves in the Iberian Peninsula, such as Emporion (Ampurias).
} 
south of France, and of Ampurias ${ }^{14}$ on the Catalan coast, the Phoenician interests in the western Mediterranean underwent several changes that also affected Ibiza. The incidence of these changes was not very significant, and the Phoenician colonies in the south of the Iberian Peninsula continued to stay in the same places and even founded new enclaves, such as Malaga or Villaricos, which progressively began to play a prominent role. Likewise, the area of influence of these colonies remained unchanged.

The fall of Tyre in $753 \mathrm{BC}$ has been considered as a cause of this scenario in the Mediterranean area. and its subsequent incorporation into the Neo-Babylonian Empire $^{15}$, which would have caused a break in the contacts that the Phoenician colonies of the far western Mediterranean had maintained with the East, a fact that could have meant their end. This possibility has been the subject of various discussions, and alternatives have been proposed (Frankenstein, 1979), among which is the one that suggests that the outbreak of the crisis was due to the decrease in demand for silver by the Neo-Assyrian Empire (911-605 BC) at the end of the 7th century BC, or in the incorporation to the Mediterranean trade routes of areas of Central Europe, whose contacts with Greeks and Etruscans allowed them to access without Phoenician intermediation, which will cause a decrease in their benefits. Nor should we forget the Greek irruption in the Mediterranean trade routes, which ventured towards the Gulf of Lion and the coasts of the Iberian Peninsula, putting an end to the Phoenician monopoly.

Ibiza was affected by the decrease in the commercial flow, which caused a decline in its economic prosperity. However, it continued to maintain contacts with the Phoenician colonies in the south of the Iberian Peninsula, but paid more attention to the central Mediterranean, maintaining frequent contacts with Sardinia and Sicily. Although not enough archaeological evidence has been found to verify this new orientation in trade relations, some of them are certainly interesting and significant. The discovery of ceramic remains similar to manufactures of Greek and Etruscan origin stands out,

\footnotetext{
${ }^{14}$ Founded by the Phocaeans in $575 \mathrm{BC}$ to the northeast of the coast of the Iberian Peninsula as a commercial enclave.

${ }^{15}$ Also called the Chaldean Empire (626-539 BC), it arose from the convulsed situation after the death of the Assyrian king Ashurbanipal in $627 \mathrm{BC}$ that triggered several warlike conflicts. Under the command of the Chaldean Nabopolassar, along with Medes, Persians, Scythians and Cimmerians, he managed to destroy Nineveh in 612 BC and constitute Babylon as a new center of power. This empire will come to an end in 539 BC when their last king, Nabonidus, is defeated by the Persians at Opis.
} 
indicating that, probably, these were acquired in Sardinia or Sicily, places with which the Phoenicians of Ibiza maintained important and frequent relations. Authors such as Maluquer (1982) raise the possibility that Ibiza had played a prominent role in the iron trade from Etruria ${ }^{16}$ to the Iberian Peninsula, a mineral in high demand by various Iberian populations for manufacturing weapons.

Thanks to the study of the funeral rites and the analysis of the different cremations in Puig des Molins, it has been possible to verify that some depositions had in their trousseau Bisi-3 type blisters, very frequent in Sardinia. This suggests the possibility that they were imported from Sardinian lands, which could indicate that the contacts between both places went beyond the merely commercial ones, becoming a cultural approach that could be increased with the arrival of new population contingents. from both Sardinia and Sicily.
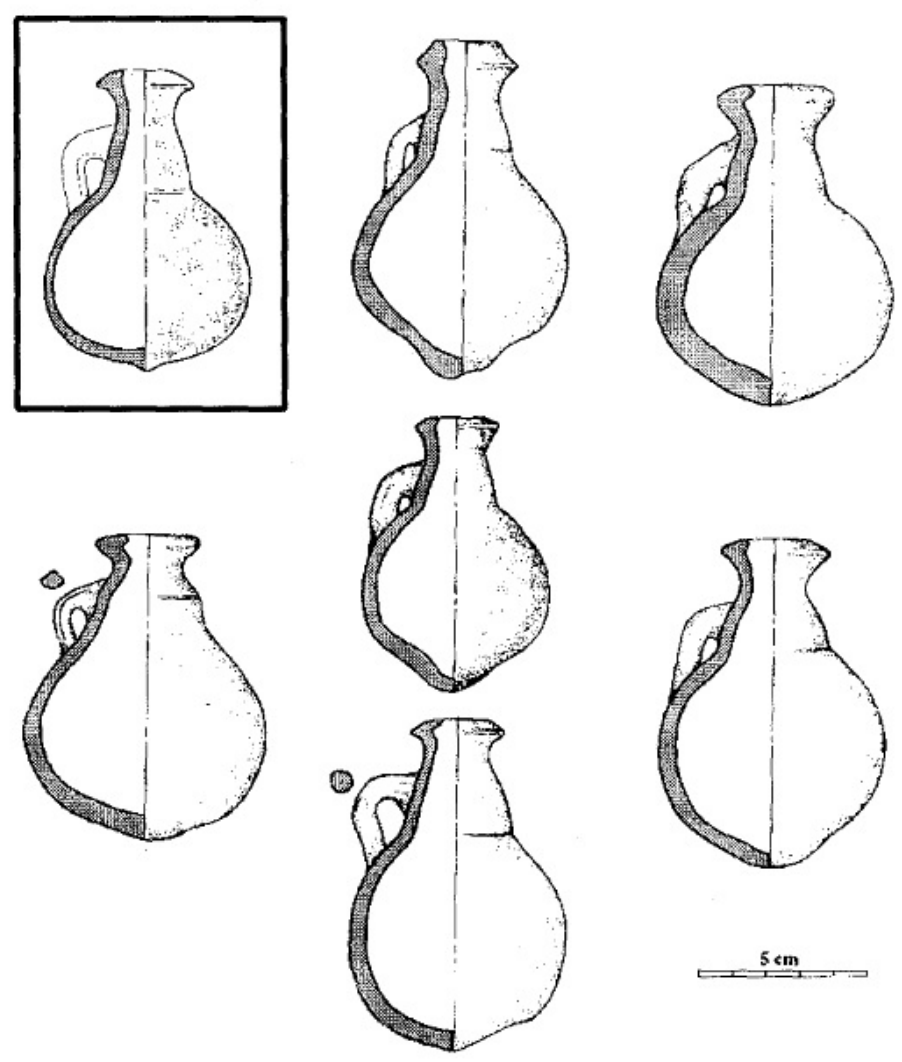

Phoenician Bisi-3 type ampoules from Puig des Molins (Ramón, 1996)

\footnotetext{
16 Named by Greeks and Romans as Tirrenia, it was an ancient region in the center of the Italian Peninsula inhabited by the Etruscans, who managed to consolidate a strong confederation, the Etruscan Dodecapolis.
} 
The finding of several pieces of silver jewelry in some Phoenician necropolises in Sardinia seems to confirm that the commercial flow between Ibiza and Sardinia was two-way. The silver, which would continue to come entirely from the Phoenician enclaves in the south of the Iberian Peninsula and the presence, albeit meager, of bucchero $^{17}$ pieces in places such as Malaga, Toscanos or Guadalhorce seem to be conclusive evidence.

Another argument in favor of this possibility is found in the production of various ceramic pieces in Ibiza itself, although so far the archaeological investigations carried out in the southern area of the necropolis of Puig des Molins have not yielded conclusive data that allow to endorse it due to the absence of stratigraphic levels prior to the 6th century BC. The analysis of the ceramic production of this time has shown that some vessels were made in Ibiza. Some ampoules, well plates and other ceramic forms, made up its ceramic catalog, whose production was especially concentrated during the second half of the 6th century BC. Regarding the morphology of the pieces, they are close to models from the central Mediterranean.
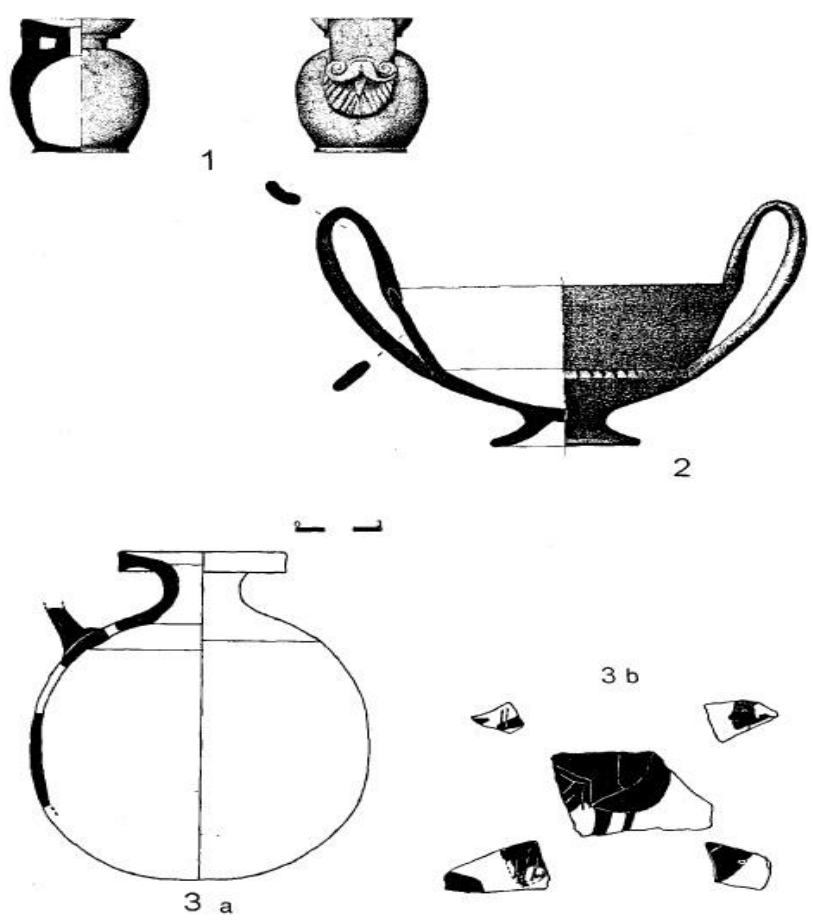

Imported ceramic pieces found in the necropolis of Puig des Molins (1) aryballos from Naucratis; (2) bucchero khantaros; (3) Corinthian aryballos

\footnotetext{
${ }^{17}$ A type of black paste pottery characteristic of the Etruscan culture. The first examples date from the beginning of the 7th century $B C$
} 
At this time there was a reaffirmation of the Phoenician identity in Ibiza thanks to frequent contacts with Etruscans, Greeks (especially from Ampurias) and Phoenicians from other colonies, which coincided with a growth of the urban nucleus due to the arrival of new settlers, reflected in its layout and architectural constructions, as well as in the greater number of lands that were destined to agricultural production, although, circumscribed to the Plá de Vila. This growth was interrupted throughout the second half of the 6th century $\mathrm{BC}$ as a result of the powerful irruption of Carthage.

\section{IBIZA UNDER CARTHAGINIAN RULE}

Among the various reasons proposed to explain the motivations that led Carthage to take control of the trade routes previously controlled by Tyre, apart from the obvious imperialist ambitions, it is convenient to take into account the weight that those of an economic nature could have. Before its rise, Carthage had benefited from the commercial flow between the Phoenician colonies of the "circle of the Strait" towards the central and eastern Mediterranean thanks to its strategic location on the North African coast of present-day Tunis, in addition to having successfully integrated as part of the Etruscan trading networks from the 7th century BC, joining forces with the Etruscans to prevent the Phocaeans from founding Massalia in $600 \mathrm{BC}$.

The fall of Tyre in 753 B.C. affected Carthage, but unlike the Phoenician colonies of the "circle of the Strait", its effects were less intense thanks to its commercial contacts in the Tyrrhenian area. Despite this, the crisis was felt in the middle of the 6th century BC, at which time Carthage considered taking control of the commercial networks of which it had only been a part. One of the first Carthaginian actions was the conquest of Sicily in $550 \mathrm{BC}$, where its influence was especially felt, later spreading to Sardinia and Ibiza.

It is in those moments when the Phoenician settlement began to spread throughout the Puig de Vila, including the port facilities in the citadel. The most evident indication of this urban expansion is found in some potteries from the middle of the 6th century BC, located to the west of the port and south of Puig des Molins, which seems to indicate the lack of available space in the area originally occupied by the population nucleus. 


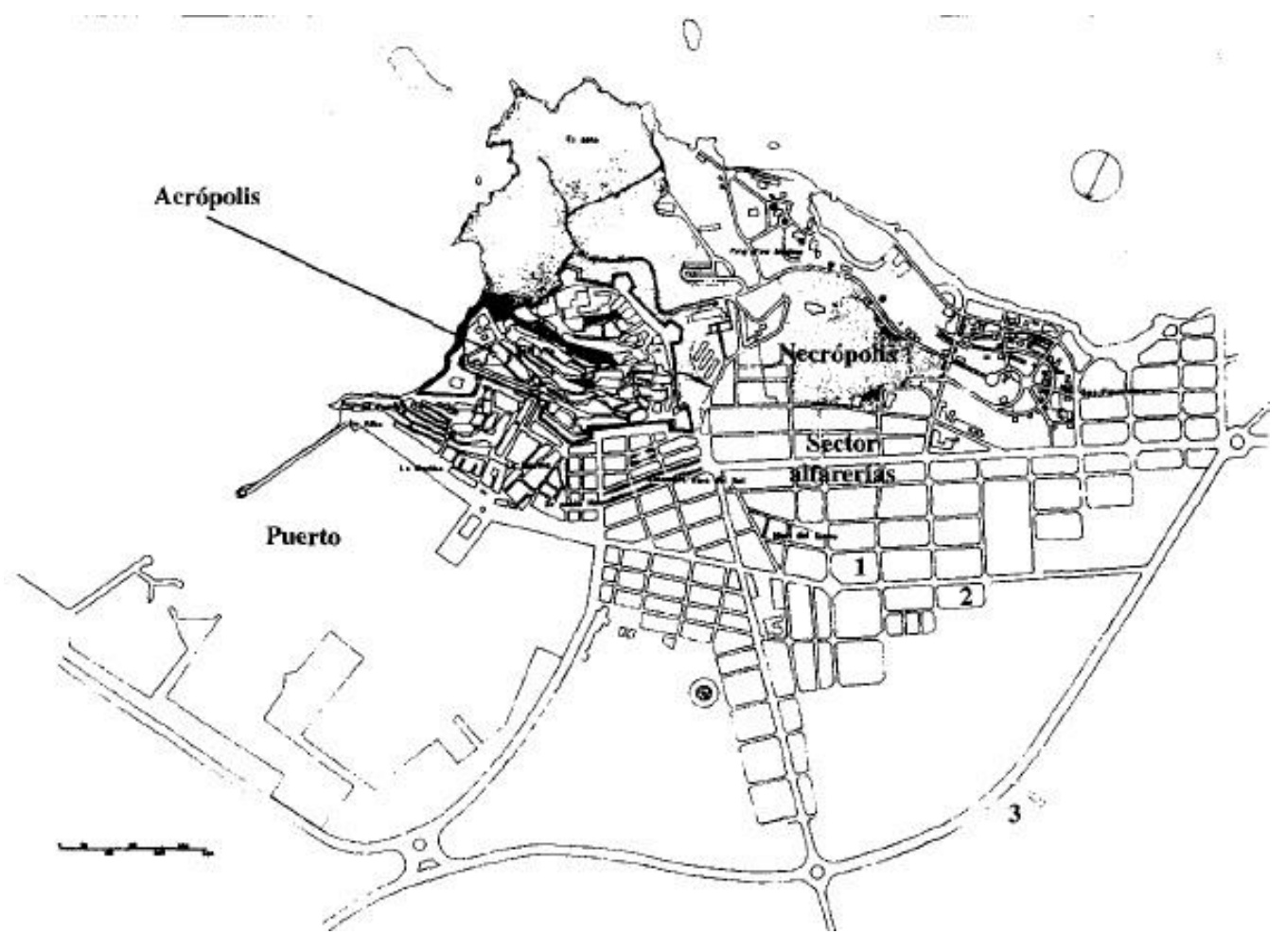

Map of Ibiza at the beginning of the Punic colonization

In the necropolis there are some changes in funeral structures and rituals. Incineration is progressively abandoned in favor of burial, which was carried out in wide hypogea and in large pits dug into the rock. The wells, rectangular in shape, stand out for their large size and for having steps on their sides to facilitate access to the burial chambers, exquisitely sculpted but lacking benches or niches.

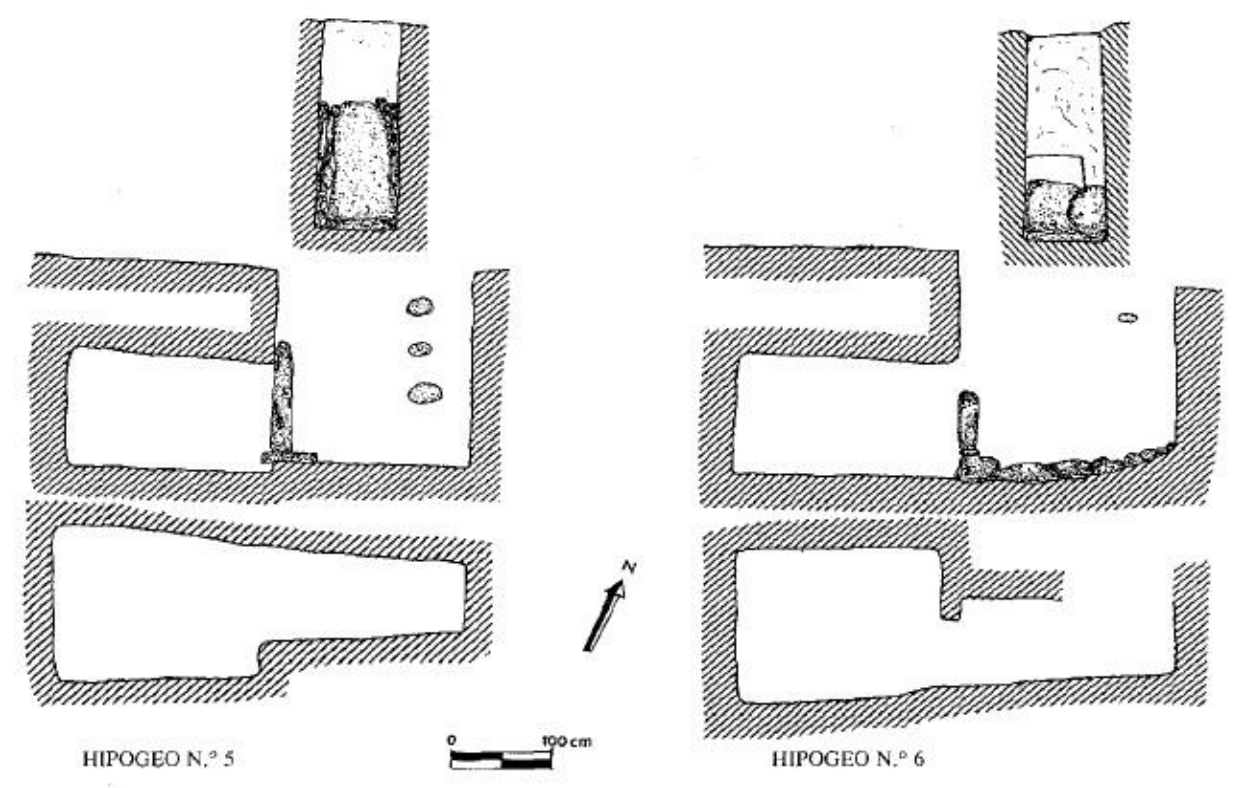

Hypogeums No. 5 and 6 of the Puig des Molins necrópolis 
Regarding the grave goods, despite being quite scarce, specimens of razors, small ceramic bowls, bitroncoconic urns and some terracotta, similar to those of the central Mediterranean have been recovered. The discovery of decorated ostrich eggshells, normally found together with small pieces of jewelry, amulets, necklace beads and scarabs, seem to confirm the progressive Carthaginian cultural impact in Ibiza.

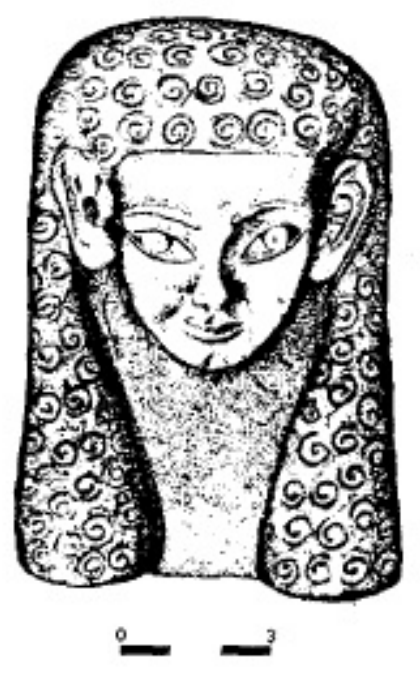

Female head of a terracotta figurine found in one of the hypogea of Puig des Molins

As part of these changes, the settlement of other areas around the bay of Ibiza began, in addition to founding two new sanctuaries in Illa Plana and in Puig d'en Valls. In the first, fragments of terracotta with clear oriental reminiscences have been found, dating to the end of the 7th century BC. or the first half of the 6th century BC. Until $550 \mathrm{BC}$ there was no religious structure in the place, as seems to indicate the discovery of some votive figurines that seem to represent anthropomorphic figures whose dating ranges between the 6th and 4th centuries BC, although the oldest dates back to the 7th century $\mathrm{BC}$.

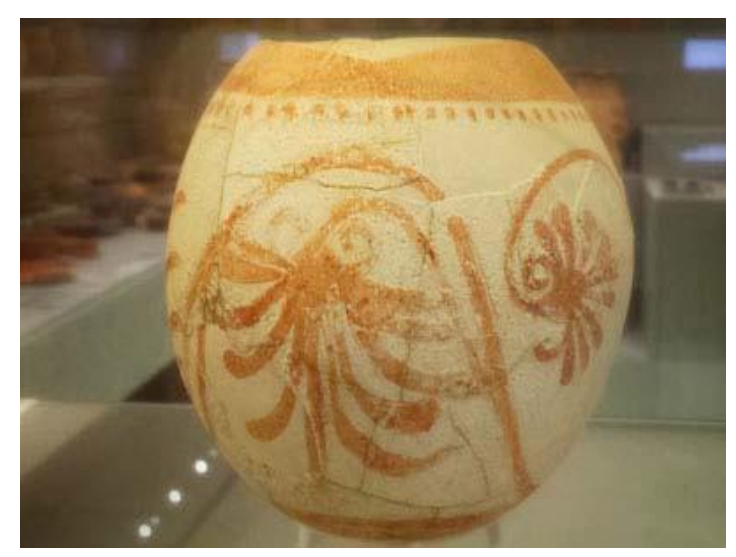

Ostrich Egg from Puig des Molins 


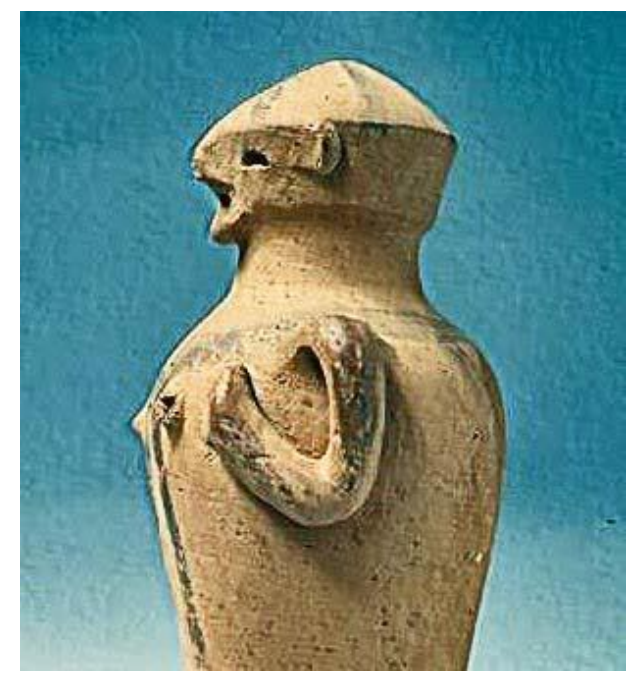

Terracotta figurine from Illa Plana

These figurines marked the arrival of a religious cult from the central Mediterranean, hitherto unknown in the Phoenician colonies of the western Mediterranean area, whose parallels were found in Carthage, as well as in some places in Sardinia. It has been speculated that they were offerings to Eshmun ${ }^{18}$, one of the main deities of the Punic pantheon (Aubet, 1969).

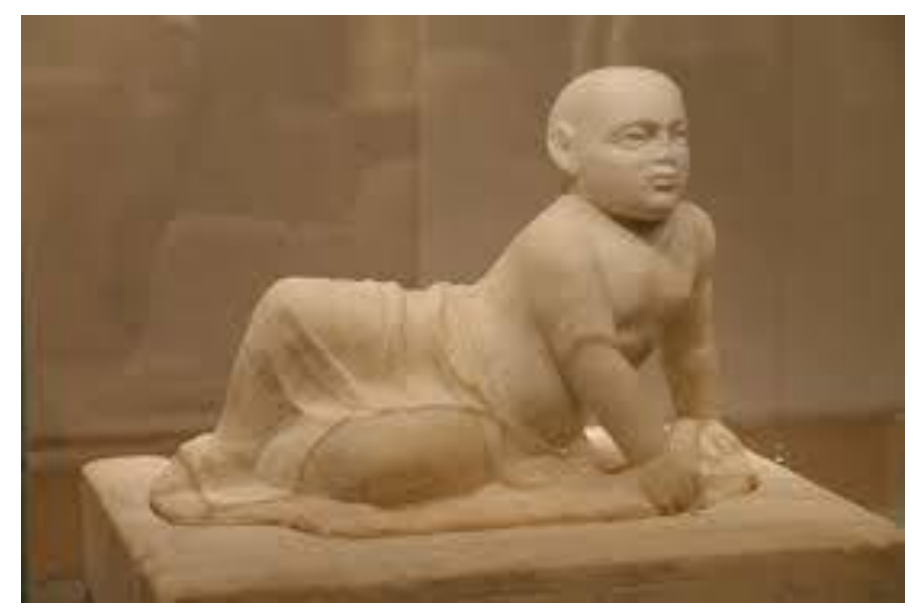

Sculpture of Eshmun preserved in the Museum of Beirut (Lebanon)

\footnotetext{
${ }^{18}$ Punic divinity associated with the health and patron of Sidon, where the remains of an ancient temple where he was worshiped are preserved. According to Phoenician mythology, he was the eighth son of Sydik and was a deity especially revered in Cyprus, Sardinia, Tyre and Carthage.
} 
Regarding the sanctuary of Puig d'en Valls, the data obtained are quite scarce. This place, strategically located in the bay of Ibiza, seems to have been occupied at the end of the 6th century BC. In its surroundings a dozen terracottas have been found, a fact that led to speculation at first that it was a place of religious worship, but currently it is believed that it was more focused on economic activities. As a consequence of the increase in agricultural exploitation near Pla de Vila, some of the inhabitants chose to settle just $2 \mathrm{~km}$ from the city to be closer to their farmland. In addition, and thanks to its proximity to the coast (less than $500 \mathrm{~m}$ ) it was also possible to carry out activities related to fishing.

Ibizan ceramic production reached its peak thanks to the constitution of an authentic artisan neighborhood that, adopting models and typologies of the central Mediterranean, produced its own pieces for everyday use. Some of these pieces have been found in grave goods, especially bitroncoconic urns and Eb-12 type jars, as well as trilobed mouths. The production of large amphoric containers similar to types PE-11 and PE-21 also began, mainly intended for the transport of various products.
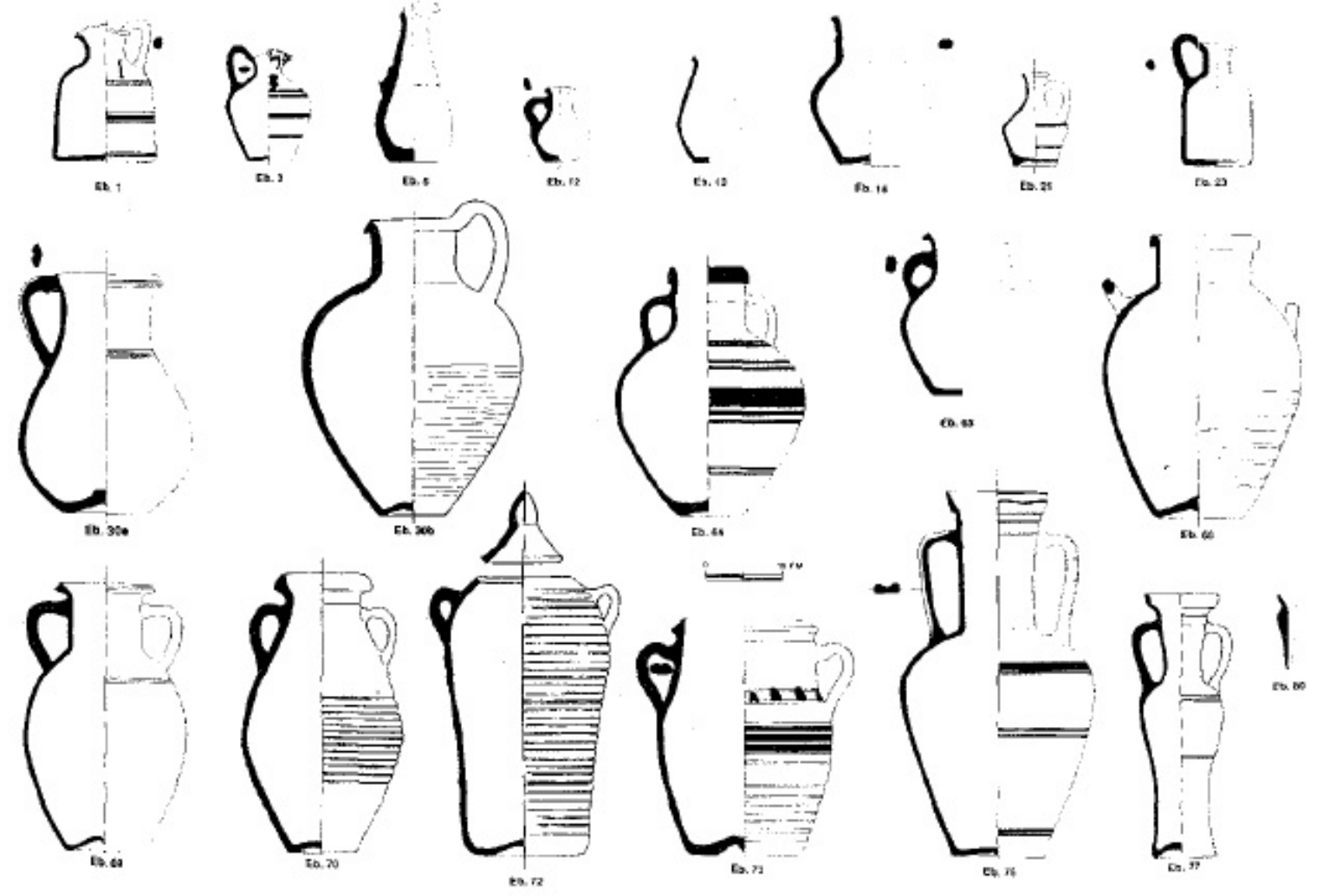

Main ceramic forms produced in the Ibizan pottery workshops 
This fact does not seem to leave any doubt about the potential of Ibizan agriculture, which managed to have more than enough surpluses to be used for export, despite the fact that no remains of rural facilities have been found prior to the 5 th century $\mathrm{BC}$ (the oldest date from around $450 \mathrm{BC}$ ), as confirmed by the findings of a red-figure lekhytos in Santa Eulalia and of a rural hypogeum in Can Marines.

Thanks to their inclusion in the Carthaginian orbit, Ibizan merchants were able to expand their radius of action to new areas of the Mediterranean, showing special interest in the northeast of the Iberian Peninsula, which led to further strengthen their relations with Ampurias, where remains of pieces of Ibizan manufacture have been recovered in the necropolis of this Greek enclave.

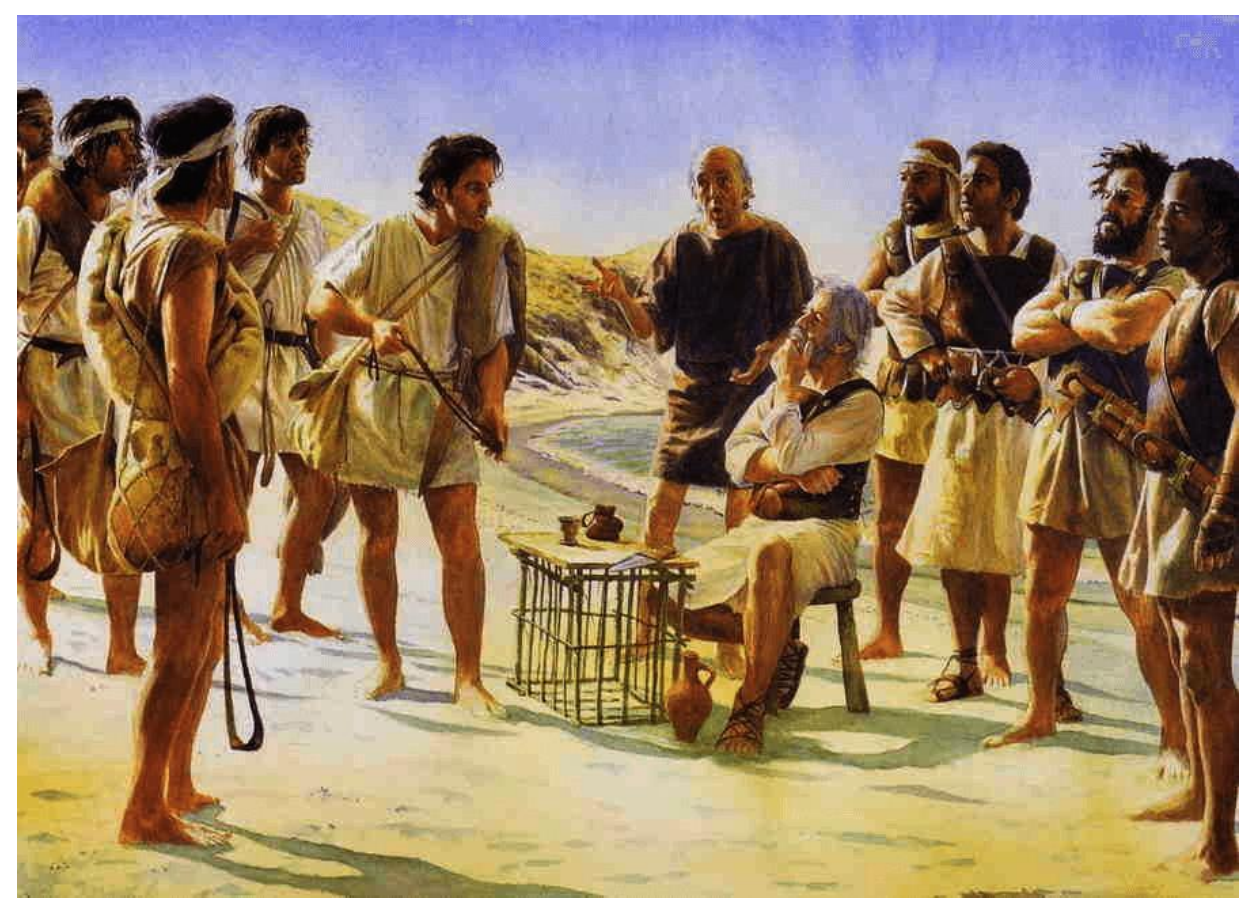

Recruitment of Balearic slingers (by Steve Noon)

They also began to frequent the coasts of southern France more frequently, as can be inferred from the imitation that the Ibizan workshops made of massaliotan-type wine amphorae, many of them recovered on the Ibizan coast. At this time, contacts with the rest of the Balearic Islands began, a fact confirmed thanks to the remains of Ibizan products found in various indigenous Talayotic settlements in Majorca and Minorca, which undoubtedly aroused the interest of the Phoenicians of Ibiza to open a new market for their products due to the large indigenous population on both islands, whose 
attractiveness as recruitment centers for mercenary forces was also a factor to be taken into account.

In the 5th century $\mathrm{BC}$ and especially during its first decades, some of these processes continued their course and consolidated the prosperity of the Ibizan enclave. Under Carthaginian rule, Ibiza was promoted to the category of city, which made it an outstanding economic and cultural center fully integrated into the Carthaginian commercial networks, but without losing its autonomy, which allowed it to continue developing their own activities and interests. Throughout the second half of that century, the island was occupied in its entirety and numerous rural settlements dedicated to agricultural activities emerged, a fact that for many authors represents the beginning of the "classical era" of Ibiza under Carthaginian rule.

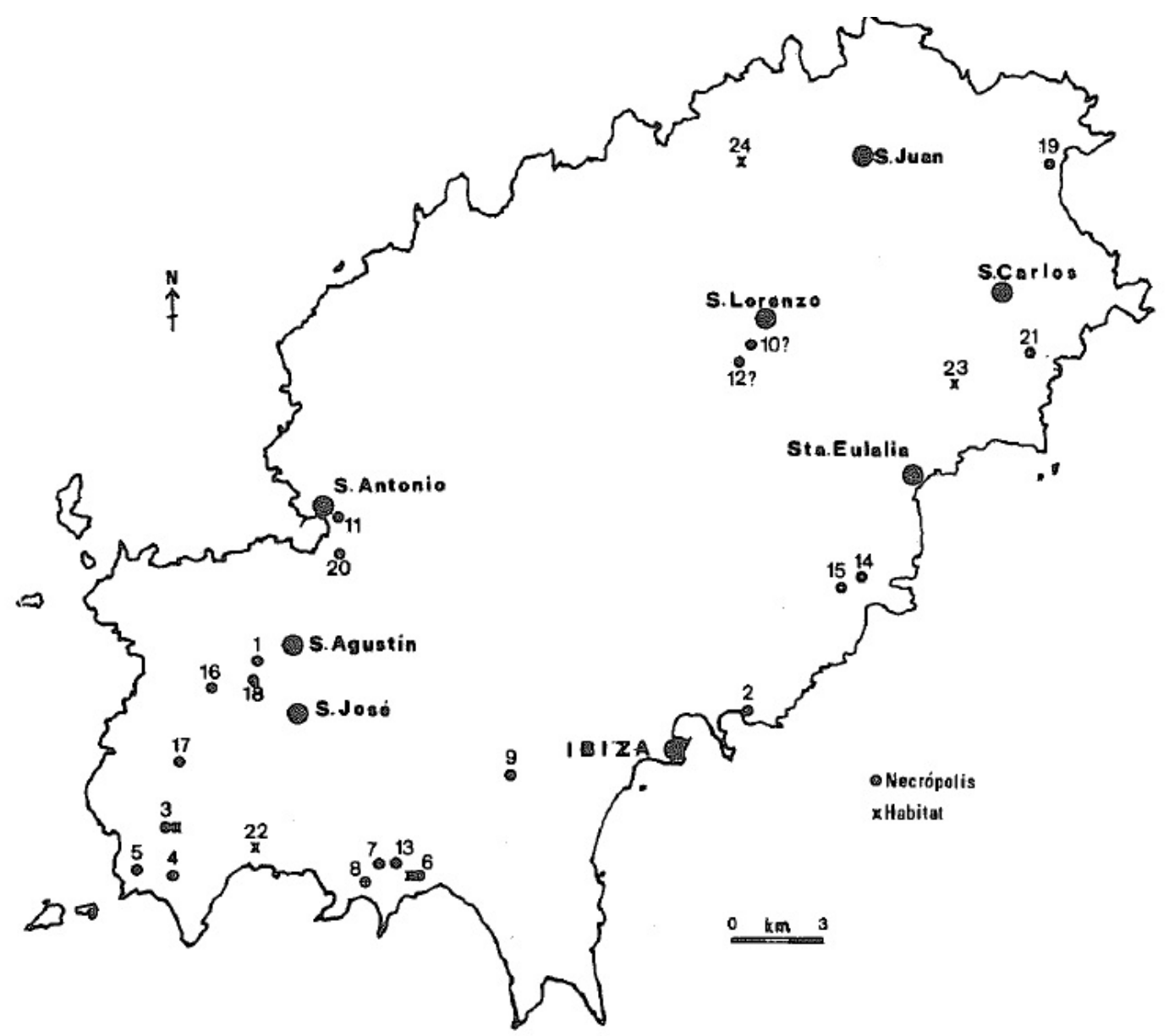

Map of the main rural settlements during Carthaginian times

1. Sa Barda. 2. Ses Torres. 3. Cala d'Hort. 4. Coll de Cala d'Hort. 5. Can Rocas. 6. Ca N'Ursul. 7. Ca Na Jondala. 8. Cas Vildu. 9. Can Cardona. 10. Can Arnau. 11. Can Rota. 12. Can Ferré. 13. Sa Torrassa. 14. Can Vic. 15. Ca Na Polla. 16. Cala Tarida. 17. Cala Vadella. 18. Can Curt. 19. Can Pere Cataiá. 20. Cas Jurat. 21. Can Marines. 22. Puig d’En Corda. 23. Can Vicent d'En Jaume. 24. S'Olivar d'Es Mallorqui. 


\section{CONCLUSION}

It can be said that the Phoenician settlement in Ibiza was framed within the commercial expansion of the Phoenician colonies in the south of the Iberian Peninsula during the 7 th century $\mathrm{BC}$, the period of its greatest height. With the founding of Ibiza, the Phoenicians sought to have an enclave that would serve as support in their navigation routes along the eastern coasts of the Iberian Peninsula and towards the Gulf of Lion, which allowed them to access new markets and products thanks to their contacts with different indigenous peoples.

Everything changed around $600 \mathrm{BC}$, when the prosperity of the Phoenician colonies of the "circle of the Strait" began to decline. This had consequences in Ibiza, but despite this, it managed to focus its activity towards the central Mediterranean area, establishing close commercial and cultural contacts with other Phoenician colonies, especially in Sardinia and Sicily. With the rise of Carthage, Punic influence was felt in Ibiza, which throughout the 6th century BC underwent various transformations as a result of the progressive Carthaginian colonization, which would end up including Ibiza in its orbit of power and experiencing outstanding prosperity by expanding its commercial networks.

\section{BIBLIOGRAPHY AND INTERNET SOURCES}

- AUBET, M. ${ }^{a}$ E., "Las colonias de Occidente II: Andalucía Mediterránea e Ibiza". In: Tiro y las colonias fenicias de Occidente, Edicions Bellaterra, Barcelona (2009) Pp. 307- 344

- COSTA, B.; FERNÁNDEZ, J.H., "Ebusus Phoenissa et Poena. La isla de Ibiza en época feniciopúnica”. In: Espacio, Tiempo y Forma, Serie I, Prehistoria y Arqueología, t.10, 1997. Pp. 391- 445

- DOMÍNGUEZ MONEDERO, A.J., "Los fenicios en Occidente”. In: SÁNCHEZ MORENO, E. (coord.); DOMÍNGUEZ MONEDERO, A.J.; GÓMEZ PANTOJA, J.L - Protohistoria y Antigüedad de la Península Ibérica vol.I (Las fuentes y la Iberia colonial), Sílex, Madrid (2008) Pp. 75-218

- GÓMEZ BELlARD, C., La necrópolis del Puig des Molins (Ibiza). Campaña de 1946, Ministerio de Cultura, Dirección General de Bellas Artes y Archivos, Subdirección General de Arqueología y Etnografía, Madrid (1984) 
"La isla de Ibiza en los siglos VII y VI a.C.” In: GÓMEZ

BELLARD, C.; COSTA RIBAS, B.; GOMEZ BELLARD, F.; GURREA BARRICARTE, R.; GRAU ALMERO, E.; MARTÍNEZ VALLE, R. - La colonización fenicia de la isla de Ibiza. Ministerio de Cultura, Dirección General de Bellas Artes y Archivos, Instituto de Conservación y Restauración de Bienes Culturales, Madrid, (1990) Pp. 173-186

- RAMÓN, J. - "The Ancient Colonization of Ibiza: Mechanisms and Process". In: BIERLING, M.R.; GITIN, S; (eds.) - The Phoenicians in Spain (An Archaeological Review of the Eighth-Sixth Centuries B.C.E.), Eisenbraus, Winona Lake (IN) (2002) Pp. 127-152

- SAN NICOLÁS PEDRAZ, Ma .P. - "La expansión fenicio-púnica en Occidente". In: ZARZALEJOS PRIETO, M.; GUIRAL PELEGRÍN, C.; SAN NICOLÁS PEDRAZ, M. ${ }^{a}$ P., Historia de la Cultura Material del Mundo Clásico, UNED, Madrid (2010) Pp. 233-257

- SAYAS ABENGOCHEA, J.J., "La colonización fenicia". In: Historia Antigua de la Península Ibérica, UNED, Madrid (2003) Pp. 65-72

- Penibaetic System: https://en.wikipedia.org/wiki/Penibaetic_System (accessed June 2021)

- Ibiza: https://en.wikipedia.org/wiki/Ibiza (accessed June 2021)

- Phoenician Encyclopedia : http://phoenicia.org/ (accessed June 2021) 